\title{
ABRAHAM W POCHWALE OJCÓW (SYR 44,19-21)
}

Abraham, obok Mojżesza i Dawida, jest jedną z najważniejszych postaci Starego Testamentu, a nawet całego Pisma Świętego. ${ }^{1}$ Nie wynika to z liczby rozdziałów Księgi Rodzaju, które opisują losy tego patriarchy i jego rodziny (zob. Rdz $11,27-25,11^{2}$ ), ale przede wszystkim z roli, jaką odegrał on w historii Izraela, oraz jego znaczenia dla rozwoju wiary w jedynego i prawdziwego Boga. ${ }^{3}$ Jest on bowiem jedną z głównych postaci pozwalających poznać i zrozumieć tożsamość, zarówno tę społeczno-socjologiczną, jak również religijną

1 „Dla autorów biblijnych Abraham był kimś więcej niż postacią historyczną. Osoba Abrahama pobudzała wyobraźnię, stanowiąc źródło wielu duchowych myśli, zarówno w ST, jak i NT. Postać Abrahama cechuje wielowymiarowość, która mogła zostać przez pisarzy biblijnych wykorzystana do celów retorycznych i motywacyjnych"; L. R y k e n, J.C. W i 1 h o it, T. L o n g m a n III, Stownik symboliki biblijnej. Obrazy, symbole, motywy, metafory, figury stylistyczne i gatunki literackie w Piśmie Świętym, „Vocatio”, Warszawa 2003.

2 Zob. J. L e m án s k i, Księga Rodzaju. II: Rozdziały 11,27 - 36,43, Nowy Komentarz Biblijny. Stary Testament I/2, Edycja Świętego Pawła, Częstochowa 2013, s. 56-57.

3 „Abraham, ojciec narodu wybranego, zajmuje miejsce szczególne w historii zbawienia. Jego powołanie nie tylko stanowi pierwszy etap urzeczywistniania Bożych planów, lecz także ukazuje zasadnicze tendencje owych planów"; R. F e u i 11 e t, A. Va n h o y e, Abraham, w: X. L é o n - D u fou r (red.), Stownik teologii biblijnej, Pallottinum, Poznań 1990, s. 37. „Na pierwsze miejsce Księga Rodzaju (J i E) wysuwa jednak nie tyle postać Abrahama jako bohatera narodowego, ile raczej fakt urzeczywistnienia się poprzez niego Bożego działania w narodzie izraelskim. Relacja o faktach historycznych jest tu czymś drugorzędnym i stanowi jedynie tło dla historii zbawienia, w której dzieje Abrahama są jej kolejnym, ważnym etapem"; S. Ł a c h, Abraham, w: H. W it c z y k (red.), Nowy słownik teologii biblijnej, Towarzystwo Naukowe KUL-Jedność, Lublin-Kielce 2017, s. 14. 
narodu wybranego. ${ }^{4} \mathrm{Z}$ jednej strony potwierdza to liczba miejsc w tekście natchnionym, w których pojawia się imię tego patriarchy (61 razy jako 'aberām i 175 'aberāhām, co w sumie daje imponującą liczbę 236; ${ }^{5} \mathrm{~W}$. Vogels, uwzględniając księgi deuterokanoniczne, podaje liczbę $246^{6}$ ), z drugiej zaś, a może przede wszystkim, określenie go jako „ojca narodu” (zob. Joz 24,3; Iz 51,2; J 8,39; Rz 4,1; Jk 2,21). ${ }^{7}$ Ojcostwo Abrahama nie dotyczy jedynie wymiaru fizycznego, ale przede wszystkim religijnego - stał się on pierwszym człowiekiem, który uwierzył w Boga i Mu służył. ${ }^{8}$ Podkreśla to często pojawiająca się w Starym Testamencie formuła: „Bóg Abrahama, Izaaka i Jakuba/Izraela" (zob. Wj 2,24; 3,6.15.16; 4,5; 6,3; 1Krl 18,36; 1Krn

4 „Auf der Ebene des bibl. Endtextes kommt Abraham die Rolle der großen, identitätsstiftenden Gestalt für das Judentum in der Gola (= Diaspora) zu, das die JHWH-Frömmigkeit übt, unbeschadet, ob in Babylonien oder Ägypten"; F. K o g e 1 (red.), Herders Neues Bibellexikon, Herder, Freiburg-Basel-Wien 2008, s. 6.

5 Zob. A. Eve n-Sh o s h a n (red.), A New Concordance of the Bible. Thesaurus of the Language of the Hebrew and Aramaic Roots, Words, Propter Names, Phrases and Synonyms, Kiryat Sefer, Jerusalem 1997, s. 11.

6 Zob. W. Vo ge 1 s, Abramo, w: R. P e n n a, G. P e r e g o, G. R a v a s i (red.), Temi teologici della Bibbia. Dizionari San Paolo, San Paolo, Cinisello Balsamo 2010, s. 7: „Nella maggior parte dei casi, si tratta di testi esilici o postesilici, il che indica che Abramo ricevette un'attenzione particolare dopo la distruzione di Gerusalemme”. Według Bosaka w Biblii (zarówno Starym, jak i Nowym Testamencie) imię Abram/Abraham występuje aż 326 razy; zob. P.C. B o s a k, Leksykon wszystkich postaci biblijnych, Petrus. Kraków 2015, s. 32.

7 Por. R.E. C l e m e n t s, 'bhrāhām, w: G.J. B o t t e r w e c k, H. R i n g g r e $n$ (red.), Theological Dictionary of the Old Testament, W.B. Eerdmans, Grand Rapids 1997, t. I, s. 53-54; R. F e u i 11 e t, A. V a n h o y e, Abraham, s. 38-40; L. H i c k s, Abraham, w: G.A. B u t t ri c k (red.), The Interpreter's Dictionary of the Bible. An Illustrated Encyclopedia, Abingdon Press, New York-Nashville 1962, t. I, s. 20; A.R. M i 11 a r d, Abraham, w: D.N. F r e e d m a n (red.), The Anchor Bible Dictionary, Doubleday, New York-London 1992, t. I, s. 35.36; S. Ł a c h, Abraham, s. 14; L. Ry k e n, J.C. W i 1 h o it, T. L o n g m a n III, Słownik symboliki biblijnej, s. 3; S. Virguli n, Abramo, w: P. Ros s a no, G. R avas i, A. Girla nd a (red.), Nuovo dizionario di teologia biblica, San Paolo, Cinisello Balsamo 1988, s. 8; W. Vo ge 1 s, Abramo, s. 7; D.H. W h e a t o n, Abraham, w: J.D. D o u g 1 a s (red.), The New Bible Dictionary, Eerdmans, Grand Rapids 1962, s. 7.

8 Zob. L. H i c k s, Abraham, s. 20. 
29,18; 2 Krn 30,6; por. Ne 9,7; Ps 47,10), ${ }^{9}$ jak i wspomnienie przymierza, które Pan zawarł z Abrahamem, Izaakiem i Jakubem (zob. Wj 2,24; 6,8; 32,13; 33,1; Kpł 26,42; Lb 32,11; Pwt 1,8; 6,10; 9,5; 29,12; 30,20; 34,4; $1 \mathrm{Krn} 16,16 ; 2 \mathrm{Krn} 13,23) .{ }^{10}$ Wyjątkowość Abrahama została podkreślona w Biblii przez fakt, że żadna inna osoba nie nosi tego imienia - jest on jedynym człowiekiem o tym imieniu w całym Piśmie Świętym. ${ }^{11}$

Rola, jaką odegrał Abraham w historii Izraela, sprawiła, że Syrach w Pochwale Ojców (Syr 44,1 - 50,29) nie mógł pominąć tak ważnej dla narodu wybranego postaci. W prezentacji dziejów swego ludu mędrzec z Jerozolimy umieścił Abrahama na trzecim miejscu (Syr 44,19-21), tuż za Henochem (Syr 44,16) i Noem (Syr 44,17-18). Co prawda poświęcił mu niezbyt wiele miejsca (w oryginalnym tekście hebrajskim perykopa poświęcona temu patriarsze liczy 10 stychów, ${ }^{12}$ zaś wersja grecka zawiera ich $13^{13}$ ), ale w pełni ukazał jego wyjątkową rolę i znaczenie dla narodu żydowskiego. Wyjątkowe i ważne miejsce w historii Izraela, które zajmuje Abraham, Syrach podkreślił

9 Zob. L. Ryke n, J.C. Wil hoit, T. L o ng m a n III, Słownik symboliki biblijnej, s. 2-3; W. Vo g e 1 s, Abramo, s. 7.

10 Zob. R.E. C 1 e m e n t s, 'bhrāhām, s. 55-56. „W ST Abraham odgrywa trzy główne role. Po pierwsze, jest ojcem narodu żydowskiego (...). Po drugie, jest pierwotnym źródłem błogosławieństwa dla narodu żydowskiego (...). I wreszcie po trzecie, jego imię jest używane dla zidentyfikowania Boga narodu żydowskiego jako «Boga Abrahama»"; N.L. C a lver t, Abraham, w: G. F. H a w th or n e, R. P. M a r t i n, D. G. R e id (red.), K. B a r d s k i (red. nauk. wyd. pol.), Stownik teologii św. Pawła, „Vocatio”, Warszawa 2010.

11 Zob. W. Voge 1 s, Abramo, s. 3.

12 Zob. P.C. B e e n t j e s, The Book of Ben Sira in Hebrew. A Text Edition of all Extant Hebrew Manuscripts and a Synopsis of all Parallel Hebrew Ben Sira Texts, Supplements to Vetus Testamentum LXVIII, Brill, Leiden-New York-Köln 1997, s. 78; The Book of Ben Sira. Text, Concordance and an Analysis of the Vocabulary. The Historical Dictionary of the Hebrew Language, The Academy of the Hebrew Language and the Shrine of the Book, Jerusalem 1973, s. 54: http://bensira.org/ navigator.php?Manuscript=B\&PageNum=27 (dostęp: 13 III 2018).

13 Zob. J. Z i e g l e r, Sapientia Iesu Filii Sirach, Septuaginta. Vetus Testamentum Graecum Auctoritate Academiae Scientiarum Gotteingensis editum XII/2, Vandenhoeck \& Ruprecht, Göttingen $1980^{2}$, s. 334. 
przez fakt postawienia go w centralnym miejscu pośród postaci opisanych w pierwszym etapie historii narodu wybranego, tj. do wyjścia z niewoli egipskiej (Syr 44,16-22). Mędrzec wygłasza pochwałę kolejno: Henocha, Noego, Abrahama, Izaaka i Jakuba. Należy ponadto podkreślić, że ojcu narodu wybranego poświęcił najwięcej miejsca spośród wcześniej wymienionych osób.

Niniejszy artykuł zostanie poświęcony Syrachowej interpretacji postaci Abrahama, której mędrzec dokonał we wspomnianej powyżej Pochwale Ojców, oraz znaczeniu patriarchy dla współczesnych mędrcowi ludzi wierzących, zagrożonych wpływami kultury hellenistycznej.

\section{Tekst Syr 44,19-21}

W naszej analizie perykopy poświęconej Abrahamowi w Pochwale Ojców oprzemy się na tekście greckim, ponieważ właśnie ta wersja tekstu Księgi Mądrości Syracha została uznana za kanoniczną. Znamy również tekst hebrajski Syr 44,19-21. Zawiera go odnaleziony w genizie kairskiej synagogi manuskrypt B. ${ }^{14}$ Porównując tłuma-

14 Zob. P.C. B e e n t j e s, The Book of Ben Sira in Hebrew, s. 78; P. B o c c a c c i o, G. B e r n a r d i, Ecclesiasticus. Textus hebraeus secundum fragmenta reperta, Editrice PIB, Roma 1986, s. 31; The Book of Ben Sira, s. 54; I. L é v i, The Hebrew Text of the Book of Ecclesiasticus, Semmitic Study Series, Brill, Leiden 1904, s. 59. Zob. http://bensira.org/navigator.php?Manuscript=B\&PageNum=27 (dostęp: 13 III 2018); por. P.C. B e e n t j e s, Ben Sira 44:19-23 - The Patriarchs Text, Tradition, Theology, w: G.G. X e r a v it s, J. Z s e n g e 11 é r (red.), Studies in the Book of Ben Sira. Papers of the Third International Conference on the Deuterocanonical Books, Shime'on Centre, Pápa, Hungary, 18-20 May, 2006, Supplements to the Journal for the Study of Judaism 127, Brill, Leiden-London 2008, s. 209-214; N. P e t e r s, Das Buch Jesus Sirach oder Ecclesiasticus, Exegetisches Handbuch zum Alten Testament 25, Aschendorff, Münster 1913, s. 380-381; t e n ż e, Hebräische Text des Buches Ecclesiasticus, Herdersche Verlagschandlung, Freiburg im Breisgau 1902, s. 231-233; R. S m e n d, Die Weisheit des Jesus Sirach erklärt, Verlag von Georg Reimer, Berlin 1906, s. 79, 423-424. Por. F.V. R e it e r e r, „Urtext “ und Übersetzungen. Sprachstudie über Sir 44,16-45,26 als Beitrag zur Siraforschung, Münchener Univesitätsschriften 12, EOS Verlag St. Ottilien, St. Ottilien 1980, 
czenie wnuka Syracha z hebrajskim pierwowzorem, dostrzegamy brak w nim dwóch stychów (44,21c-d), które zawiera wersja grecka. ${ }^{15}$ Istnienie ich w tekście Księgi Mądrości Syracha potwierdza również wersja syryjska. ${ }^{16}$

Tłumaczenie tekstu greckiego, który będziemy analizować w niniejszym artykule:
"19 Abraham - wielki ojciec mnóstwa narodów,
i nie została znaleziona skaza $\mathrm{w}$ chwale, ${ }^{17}$

s. 94-108. Tłumaczenie tekstu hebrajskiego zob. C. M o p s i k, La Sagesse de ben Sira, Les Dix Paroles, Verdier, Paris 2003, s. 279-280; V. M o r 1 a, Los manuscritos hebreos de Ben Sira. Traducción y notas, Asociación Bíblica Española 59, Editorial Verbo Divino, Estella 2012, s. 285-286; M.C. P a 1 m is a n o, Siracide. Introduzione, traduzione e commento, Nuova versione della Bibbia dai testi antichi 34, San Paolo, Cinisello Balsamo 2016, s. 417-419; Por. N. P e t e r s, Hebräische Text des Buches Ecclesiasticus, s. 407; R. P e t r a g 1 i o, Il libro che contamina le mani. Ben Sirac relegge il libro e la storia d'Israele, Teologia IV, Edizioni Agustinus, Palermo 1993, s. 65 - na temat możliwych przyczyn różnic w tłumaczeniu tekstu hebrajskiego Syr 44,19-21 zob. s. 72-74; P.W. S k e h a n, A.A. D i L e 11 a, The Wisdom of Ben Sira, The Anchor Bible 39, Doubleday, New York-London-Toronto 1987, s. 504; J. Ve 11 a, Eclesiastico, w: A.T. F e r n á n d e z (red.), La Sagrada Escritura. Texto y comentario. Antiguo Testamento V: Eclesiástico, Isaía, Jeremías, Ezequiel, La Editorial Catolica, S.A., Madrid: 1970, s. 188-189; B.M. Z a p f f, Jesus Sirach 25 - 51, Die Neue Echter Bibel. Altes Testament, Echter, Würzburg 2010, s. 322-323.

15 Zob. P.C. B e e n t j e s, Ben Sira 44:19-23 - The Patriarchs Text, Tradition, Theology, s. 212; B.G. G r e g o r y, Abraham as the Jewish Ideal: Exegetical Traditions in Sirach 44:19-21, CBQ 1/2008, s. 77-79; C. M o p s i k, La Sagesse de ben Sira, s. 280; V. M o r l a, Los manuscritos hebreos de Ben Sira, s. 286; G. S a u e r, Jesus Sirach/Ben Sira, Das Alte Testament Deutsch. Apokryphen 1, Vandenhoeck \& Ruprecht, Göttingen 2000, s. 303; J. Ve 11 a, Eclesiastico, s. 189.

16 Zob. N. C a l d u c h-B e n a ge s, J. F e r r e r, J. L i e s e n, La sabiduría del escriba, Biblioteca Midrásica 26, Editorial Verbo Divino, Estella 2003, s. 244.

17 Tekst drugiego stychu w wydaniu tekstu Syr pod redakcją A. Rahlfsa brzmi inaczej: ouch heurethē homoios en tē [i] doksē [i] (,,nie został znaleziony [nikt] podobny w chwale"); zob. A. R a h 1 f s (red.), Septuaginta. Id est Vetus Testamentum graece iuxta LXX interpretes. II: Libri poetici et prophetici, Deutsche Bibelgesellschaft, Stuttgart 1979, s. 456. „L'attuale lettura del greco homoios («uguale»), potrebbe forse derivare da una corruzione, nel corso della copiatura dei manoscritti, dell'originario mōmos («macchia»)"; M.C. P a 1 m i s a n o, Siracide, s. 417. 


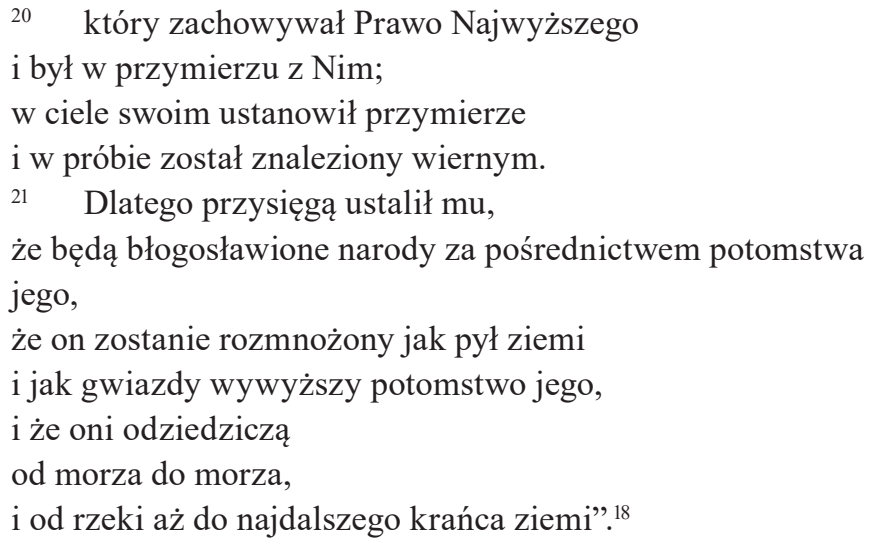

\section{Analiza Syr 44,19-21}

Struktura perykopy poświęconej Abrahamowi jest wyraźnie zarysowana i opiera się przede wszystkim na kryterium treściowym. W 44,19 Syrach w sposób ogólny przedstawia postać Abrahama, wskazując na dwa główne aspekty jego życia (liczne potomstwo w. 19a i doskonałość moralno-religijną - w. 19b). Dalsze stychy poświęcone patriarsze rozwijają początkowe stwierdzenia na jego temat. W 44,20 mędrzec ukazał, na czym polega nieskazitelność

Por. T.R. L e e, Studies in the Form of Sirach 44-50, Society of Biblical Literature. Dissertation Series 75, Scholars Press, Atlanta 1986, s. 219; R. P e t r a g 1 i o, Il libro che contamina le mani, s. 65 .

18 Tłumaczenie tekstu greckiego Syr 44,19-23 por. W. K r a u s, M. K a r r e r (red.), Septuaginta Deutsch. Das griechische Alte Testament in deutscher Übersetzung, Deutsche Bibelgesellschaft, Stuttgart 2009, s. 1152; M. W o j c i e c h o w s k i (tłum.), Księgi greckie. Przekład interlinearny z kodami gramatycznymi i indeksem form podstawowych, „Vocatio“, Warszawa 2008, s. 678-679; M.C. P a $1 \mathrm{~m}$ i s a n o, Siracide, s. 417-419; A. P i e t e r s m a, B.G. W r i g h t (red.), A New English Translation of the Septuagint. And the Other Greek Translations Traditionally Included under that Title, Oxford University Press, New York-Oxford 2007, s. 756; R. P o p o w s k i (tłum.), Septuaginta czyli Biblia Starego Testamentu wraz z ksieggami deuterokanonicznymi i apokryfami, „Vocatio“, Warszawa 2013, s. 1258. 
Abrahama, zaś w 44,21 rezultaty jego postawy wyrażone w formie obietnic odnoszących się do jego potomstwa. W centrum pochwały ojca narodu żydowskiego znajduje się idea przymierza $(44,20 \mathrm{bc})$ i wiernego zachowywania jego przepisów (44,20a.d) ${ }^{19}$ M.C. Palmisano w ten sam sposób określa strukturę pozostałych wersetów perykopy poświęconej pochwale Abrahama, choć inaczej widzi rolę 44,20 i 44,21. Jej zdaniem, pierwszy z nich opisuje czyny patriarchy, drugi zaś działanie Boga względem niego. ${ }^{20}$

$$
\text { Tytuł - nagłówek (Syr 44,19a) }
$$

Imię „Abraham” w dziele Syracha pojawia się jedynie dwa razy. Po raz pierwszy spotykamy je na początku perykopy poświęconej temu patriarsze w 44,19 a, po raz drugi zaś w 44,22b. Ten ostatni werset w sposób bardzo syntetyczny (zaledwie w dwóch stychach) ujmuje całe życie Izaaka. Mędrzec stwierdza, że wszystko to, co otrzymał Abraham, zostało przekazane jego synowi jako spadkobiercy i kontynuatorowi misji wyznaczonej przez Boga ich rodzinie.

W pierwszym stychu perykopy poświęconej Abrahamowi Syrach w sposób bardzo ogólny wskazuje na wielkość i wyjąatkową doniosłość tego patriarchy. Czyni to w podwójny sposób: przez użycie przymiotnika ,wielki” (megas) ${ }^{21}$ oraz dzięki stwierdzeniu, że jest on „ojcem mnóstwa narodów” ( pater plèthous ethnōn).

Przymiotnik megas w odniesieniu do osób w greckiej wersji dzieła Syracha najczęściej określa Boga (zob. Syr. 39,6; 43,5.28.29 i 46,5), dwukrotnie podkreśla Jego przymioty: w 3,20 potęgę Bożą, zaś w 17,29 miłosierdzie Pana i Jego przebaczenie. Poza Abrahamem jedynie trzech innych ludzi zostało uznanych przez mędrca

19 Zob. B.G. G r e g o r y, Abraham as the Jewish Ideal: Exegetical Traditions in Sirach 44:19-21, s. 77.

20 Zob. M.C. P a $1 \mathrm{~m}$ i s a n o, Siracide, s. 418.

${ }^{21}$ Zob. B.G. W r i g h t, No Small Difference. Sirach's Realtionship to Its Hebrew Parent Text, Society of Biblical Literature Septuagint and Cognate Studies Series 26, Scholars Press, Atlanta 1989, s. 156-157. 
za wielkich. Są to Mojżesz, który ocalił Izraela z Egiptu (zob. 46,1), Izajasz - wielki prorok (zob. 48,22) oraz arcykapłan Szymon, syn Oniasza (zob. 50,1). Abraham w oczach Syracha przynależy więc do wąskiego i bardzo elitarnego grona przodków narodu wybranego, którzy zasłużyli na miano „wielki”. Mówiąc o wielkości w odniesieniu do ludzi, powinniśmy przywołać także trzy inne teksty z Księgi Mądrości Syracha, które w sposób ogólny mówią o wielkości człowieka. Syr 3,18 stwierdza, że człowiek, „który się uniża, jest wielki” (hosō[i] megas ei tosoutō [i] tapeinou seauton) i dzięki tej postawie „znajdzie łaskę u Pana” (enanti kyriou heurēseis charin). Nikt (ani przywódca ludu, ani sędzia) „nie jest większy od tego, kto boi się Pana" (zob. 10,24: ouk estin autōn tis meidzōn tou foboumenou ton kyrion). Wielkość człowieka polega więc na przyjęciu postawy bojaźni wobec Boga. Potwierdza to również Syr 25,10, gdzie mowa jest o tym, że „wielki jest ten, kto znalazł mądrość” (megas ho heurōn sofian), ale ,większy od niego jest ten, kto boi się Pana” (all' ouk estin hyper ton foboumenon ton kyrion). W Syr 44,19a przymiotnik megas możemy odnieść bezpośrednio albo do samego Abrahama („Wielki Abraham - ojciec mnóstwa narodów”) lub uznać, że określa on rzeczownik patēr („Abraham - wielki ojciec mnóstwa narodów”). ${ }^{22}$ Wydaje się, że ta ostatnia interpretacja jest bardziej właściwa, ponieważ wyjaśnia, na czym polegała wielkość tego patriarchy - odnosi się ona do faktu, że z niego wywodzą się liczne narody.

Syntagma pater plèthous ethnōn jest dosłownym cytatem z Rdz 17,423 (A.A. Di Lella w powyższym określeniu dostrzega aluzję

22 Zob. B.G. G r e g o r y, Abraham as the Jewish Ideal: Exegetical Traditions in Sirach 44:19-21, s. 67, przyp. 3.

23 Zob. A.A. D i L e 11 a, Ben Sira's Praise of the Ancestors of Old (Sir 44-49): The History of Israel as Parenetic Apologetics, w: N. C a ld u c h- B e n a g e s, J. L i e s e n (red.), History and identity: how Israel's authors viewed its earlier history, International Society for the Study of Deuterocanonical and Cognate Literature. International Conference, de Gruyter, Berlin-New York 2006, s. 160; B.G. Gre g o r y, Abraham as the Jewish Ideal: Exegetical Traditions in Sirach 44:19-21, s. 67; J.G. S n a it h, Ecclesiasticus or The Wisdom of Jesus Son of Sirach, 
również do $\mathrm{Rdz} 12,2-3 ; 15,5$ i Iz 51,2; ${ }^{24}$ G. Sauer poszerza tę listę o Rdz 13,16 i 22,17-1825). Słowa te należą do opisu przymierza, jakie Bóg zawarł z Abramem. Odnoszą się one do ludowej etymologii imienia Abrahama (zob. Rdz 17,5: ou klèthēsetai eti to onoma sou Abram all' estai to onoma sou Abraam hoti patera pollōn ethnōn tetheika se). ${ }^{26}$ Powinniśmy zauważyć, że ojcostwo Abrahama nie odnosi się jedynie do Izraela, ${ }^{27}$ ale jest ono rozszerzone poza ten naród i dotyczy także wielu innych narodów (T. Maertens i G. Sauer rozciągają ojcostwo Abrahama, o którym jest mowa w Syr 44,19a, na całą ludzkość ${ }^{28}$ ). Wskazuje na to rzeczownik ethnos, który użyty w liczbie mnogiej najczęściej odnosi się do innych narodów - pogan (por. Syr 29,18; 39,4 i 49,5; wyraźnie podkreśla to Syr 17,17, gdzie narody zostały przeciwstawione Izraelowi) w przeciwieństwie do $\lambda \alpha$ ó $\varsigma$

The Cambridge Bible Commentary, Cambridge University Press, Cambridge 1974, s. 219.

24 Zob. P.W. S k e ha n, A.A. D i L e 11 a, The Wisdom of Ben Sira, s. 505.

25 Zob. G. S a u e r, Studien zu Ben Sira, BZAW 440, De Gruyter, Berlin-Boston 2013, s. 93.

${ }^{26}$ Zob. P.C. B e e n t j e s, Ben Sira 44:19-23 - The Patriarchs Text, Tradition, Theology, s. 212, 214, 215; K.P. K ow a 1 i k, Postać Abrahama w świetle Księi Syracha, w: W. Chrostow s k i (red.) Przeznaczyteś nas dla Twojej prawdy (4Q 495). Studia dla Dr. Zdzisława J. Kapery w 65. rocznice urodzin, Rozprawy i Studia Biblijne 29, Warszawa 2007, s. 426; M.C. P a $1 \mathrm{~m}$ i s a n o, Siracide, s. 417-418; G. P é r e z R o d ríg u e z, Eclesiástico. Biblia Comentada IV, Libros Sapienciales, Biblioteca de Autores Cristianos 218, La Editorial Catolica, Madrid 1967², s. 1274; J. S c h r e i n e r, Patriarchen im Lob der Väter (zu Sir 44), w: K. K i e s o w, T. M e u re r (red.), Textarbeit: Studien zu Texten und ihrer Rezeption aus dem Alten Testament und der Umwelt Israels. FS P. Weimar, AOAT 294, Münster 2003, s. 439; B.M. Z a p f f, Jesus Sirach 25 - 51, s. 322.

27 Zob. R. P e t r a g 1 i o, Il libro che contamina le mani, s. 69-70.

28 „Von ihm [Abraham - przyp. autora] her nimmt die ganze Geschichte der Menschheit ihren Ausgangspunkt. Er wird daher als der ,Vater ${ }^{6}$ aller Menschen bezeichnet"; G. S a u e r, Jesus Sirach/Ben Sira, s. 304. Por. T. M a e r t e n s, L'Éloge des Pères (Ecclesiastique XLIV-L), Lumiere et vie 5, Editions de l'Abbaye de Saint-Andre, Bruges 1956, s. 52; zob. B.M. Z a p ff, Jesus Sirach 25 - 51, 322. 
rozumianego jako „naród wybrany” (por. Syr 48,15.16; 50,17.19.26). ${ }^{29}$ Potomstwa Abrahama, o którym jest mowa w Syr 44,19a, G. Sauer nie ogranicza jedynie do wymiaru cielesnego, ale rozszerza je również na aspekt duchowy, jak to uczynił św. Paweł. ${ }^{30} \mathrm{~W}$ ten sposób ojcostwo patriarchy obejmuje znacznie więcej osób i narodów.

Porównując Syr 44,19a z Rdz 17,4-5, wyraźnie dostrzegalne jest podkreślenie wielkości Abrahama (zarówno w tekście hebrajskim, jak i greckim Rdz 17,4-5 brakuje przymiotnika ,wielki”31). Również w tekstach z pierwszej księgi Starego Testamentu, do których odnosi się mędrzec $\mathrm{w}$ pierwszym stychu analizowanej przez nas perykopy, brakuje podkreślenia wielkości tego patriarchy. Syrach zaś określa go jako wielkiego. Jego wielkość odnosi się przede wszystkim do bycia protoplastą wielu narodów - na pierwszym miejscu oczywiście Izraela, ale nie tylko. B.C. Gregory akcentuje, że Syrach uważa obietnicę złożoną Abrahamowi w Rdz 17,4-5 za już spełnioną w czasach, w których żył mędrzec. ${ }^{32} \mathrm{~W}$ świetle przytoczonych powyżej tekstów z Księgi Mądrości Syracha, mówiących na temat wielkości człowieka (zob. Syr 3,18; 10,24 i 25,10), możemy przypuszczać, że w opinii mędrca z Jerozolimy wielkość Abrahama polegała także na tym, iż był on człowiekiem, którego charakteryzowała bojaźń Boża. Zdają się to potwierdzać dalsze stychy poświęcone jego osobie (zwłaszcza 44,20a, gdzie mowa jest o tym, że przestrzegał on doskonale Prawa Najwyższego; a także 44,20d, który odnosi się do całkowitego jego posłuszeństwa w obliczu próby).

29 Zob. G. B e r t r a m, ethnos, ethnikos. A. People and Peoples in the LXX, w: G. K it t e 1 (red.), Theological Dictionary of the New Testament, Eerdmans, Grand Rapids 1995, t. II, s. 364-369; R.C. Tr e n c h, Trench's Synonyms of the New Testament, Hendrickson, Peabody 1989, s. 387-388.

30 Zob. G. S a u e r, Studien zu Ben Sira, s. 93-94.

31 Zob. M.C. P a $1 \mathrm{~m}$ is a n o, Siracide, s. 417; R. P e tra g 1 i o, Il libro che contamina le mani, s. 65. „It is unlikely that a scribe would omit 'great' in light of what follows, while it is perfectly understandable that a scribe would add it as a gloss"; B.G. G r e g o r y, Abraham as the Jewish Ideal: Exegetical Traditions in Sirach 44:19-21, s. 67 przyp. 3.

32 Zob. tamie, s. 67. 
G. Sauer zwraca uwagę na zaskakujący, jego zdaniem, fakt odnoszący się do początku perykopy prezentującej w Pochwale Ojców postać Abrahama. Zdaniem tego egzegety, zadziwiające jest, że Syrach nie zaczął opisu tej postaci od Rdz 12, czyli powołania patriarchy, czy chociażby od Rdz 15 - zapowiedzi licznego potomstwa i przymierza, a uczynił to poniekąd od końca, tzn. poczynając od zrealizowania się danego przyrzeczenia dotyczącego licznego potomstwa. ${ }^{33}$ Niemiecki badacz uważa, że 44,19 stanowi nagłówek obejmujący całe życie Abrahama. ${ }^{34}$

W drugim stychu Syr 44,19 mędrzec stwierdza, że Abraham nie skalał się podczas całego swojego życia, tzn. nie uczynił niczego, co mogłoby negatywnie rzutować na jego osobę. Innymi słowy, nie popełnił żadnego czynu niemoralnego (ouch heurethē mōmos - „nie została znaleziona skaza"). Co więcej, Syrach pośrednio stwierdza, że wszystko, co uczynił i czego dokonał patriarcha, było wyjątkowo chwalebne, co wyraża przez odniesienie do niego rzeczownika doksa (,chwała”).

Kluczowym słowem w ocenie życia i działalności Abrahama w ujęciu mędrca z Jerozolimy jest rzeczownik mōmos („skaza”, „plama”, „hańba”, „,nagana”, „zarzut”). W greckiej wersji Księgi Syracha słowo to występuje poza 44,19b jeszcze sześć razy. W 11,31.33 i 18,15 odnosi się do publicznej nagany lub zarzutu, których należy się wystrzegać, by ich nie ściągnąć na siebie. Zaś w 20,24 złą skazą/ hańbą zostało określone kłamstwo. Powinniśmy zwrócić jednak szczególną uwagę na Syr 33,23 i 47,20, ponieważ w tekstach tych występuje syntagma didonai mōmon en tē[i] doksē [i] sou (dosł. „dać skazę/plamę w sławie twojej”). W 33,23 mędrzec wzywa, by tak postępować, żeby nie spowodować i nie sprowadzić „na swoje dobre imię żadnej hańby" (mē dō[i]s mōmon en tē [i] doksē [i] sou). W 47,20 wyrażenie to odnosi do Salomona, który sprowadził „hańbę na siebie i swoje potomstwo" (edōkas mōmon en tē [i] doksē [i] sou

33 Zob. G. S a u e r, Studien zu Ben Sira, s. 93, 94.

34 Zob. tamże, s. 93. 
kai ebebēlōsas to sperma sou). ${ }^{35} \mathrm{~W} 47,20$ zwrot „dać skazę/plamę w chwale twojej" tworzy z czasownikiem bebēloō (,profanować”, „kalać”, „bezcześcić”) paralelizm synonimiczny. B.M. Zapff uważa, że Syrach w 44,19a wprost nawiązał do $47,20 .{ }^{36}$ Na podstawie użycia rzeczownika mōmos w greckiej wersji księgi możemy powiedzieć, że wyraża on w sposób ogólny, a co za tym idzie również nieprecyzyjny, hańbę lub zarzut, które ktoś może na siebie sprowadzić przez naganne postępowanie, nie precyzując dokładniej, o jakiego rodzaju działanie chodzi. Odbierają one człowiekowi dobre imię i sprowadzają na niego niesławę oraz wstyd. ${ }^{37}$

W innych księgach LXX słowo to (mōmos) odnosi się do szeroko pojętej ułomności fizycznej zwierząt lub ludzi, która sprawia, że te pierwsze nie mogą zostać ofiarowane Bogu, ${ }^{38}$ drudzy zaś, jeśli są kapłanami, nie mogą składać ofiar. ${ }^{39}$ Ponadto ludzie, którzy są wolni od jakiejkolwiek skazy fizycznej, są uważani za ideały piękna. ${ }^{40}$ W świetle znaczenia mōmos, które przyjmuje ono w innych księgach LXX, wypowiedź Syr 44,19b możemy ująć jeszcze w inny sposób. Mędrzec, mówiąc o tym, że nie została w Abrahamie znaleziona żadna skaza, być może chciał przekazać swym czytelnikom informację odnoszącą się do fizycznej doskonałości i ludzkiego piękna ciała patriarchy. Wydaje się jednak, że ze względu na odniesienie skazy/ plamy do chwały powinniśmy wykluczyć tę ostatnią interpretację, ale pewną aluzję do ludzkiej doskonałości i piękna Abrahama możemy poniekąd uznać i nie pomijać jej zupełnie.

35 Zob. P.W. S ke ha n, A.A. D i L e 11 a, The Wisdom of Ben Sira, s. 505; por. B.G. G r e g o r y, Abraham as the Jewish Ideal: Exegetical Traditions in Sirach 44:19-21, s. 67-68.

36 „Die Aussage von 19b findet sich in den alttestamentlichen Vätererzählung nicht. Sie ist wohl vor dem Hintergrund von 47,20 zu verstehen"; B.M. Z a p ff, Jesus Sirach 25 - 51, s. 322.

37 Zob. T. Mu r a o k a, A Greek-English Lexicon of the Septuagint, Peeters, Louvain-Paris-Walpole 2009, s. 470-471.

38 Zob. Kpł 22,20.21.25; Lb 19,2; Pwt 15,21.21; $17,1$.

39 Zob. Kpł 21,17.18.21.21.23.

40 Zob. 2Sm 14,25; Pnp 4,7; por. Kpł 24,19.20. 
W Syr 44,19b tekst nie wskazuje osoby/osób, które są podmiotem formy w stronie biernej heurethe (,został znaleziony”). Możemy więc uznać, że odnosi się ona zarówno do Boga (passivum theologicum), jak i do ludzi. Również w ten sposób została podkreślona doskonałość moralno-religijna Abrahama. Nie tylko ludzie nie dostrzegli w nim najmniejszego grzechu czy braku moralnego, ale również Bóg - Ten, który wszystko widzi i o wszystkim wie, nie znalazł w nim niczego nagannego i godnego potępienia. Syrach uważa więc patriarchę za człowieka doskonałego moralnie, który nie zhańbił się najmniejszym nawet złym czynem i nie popełnił żadnego grzechu czy nieprawości. ${ }^{41}$ Jest on więc idealnym wzorem do naśladowania, który wykazuje, że doskonałość moralna i religijna jest możliwa do osiągnięcia przez człowieka. Następne stychy ukazują, jak Abraham osiągnął ją oraz w jaki sposób również każdy człowiek może ją zrealizować w swym życiu.

Wielu egzegetów odnosi treść Syr 44,19b do wydarzeń opisanych w Rdz 12,9-20 (pobyt Abrahama i jego rodziny w Egipcie) oraz do Rdz 20,1-18 (Abraham w Gerarze). ${ }^{42}$ Oba te opowiadania mają tę samą treść i mówią o Abrahamie, który, bojąc się, że zostanie zabity z po-

${ }^{41}$,[Syrach - przyp. autora] Przedstawia go [Abrahama - przyp. autora] jako człowieka godnego sławy, który ustrzegł się wszelkiej nieprawości i wypełnił nakazy, jakie Bóg dał mu w zawartym przymierzu. Autor księgi zdaje się nie dostrzegać w historii Abrahama żadnych rozterek i wahań, jakie były przecież w życiu patriarchy"; K.P. K o w a 1 i k, Postać Abrahama w świetle Księgi Syracha, s. 426.

42 Początek powyższej interpretacji dał R. S m e n d, Die Weisheit des Jesus Sirach erklärt, s. 423. Do grona zwolenników tej interpretacji należą: A.A. D i L e 11 a, Ben Sira's Praise of the Ancestors of Old (Sir 44-49): The History of Israel as Parenetic Apologetics, s. 160; N. P e t e r s, Das Buch Jesus Sirach oder Ecclesiasticus, s. 381; J. S c h r e i n e r, Patriarchen im Lob der Väter (zu Sir 44), s. 439; P.W. S k e h a n, A.A. D i L e 11 a, The Wisdom of Ben Sira, s. 505. Por. P.C. B e e n t j e s, Ben Sira 44:19-23 - The Patriarchs Text, Tradition, Theology, s. 218; B.G. G r e g o r y, Abraham as the Jewish Ideal: Exegetical Traditions in Sirach 44:19-21, s. 67-69; T. R a s h B r o w n, Sinners, Idol-Worshippers and Fools among the Men of Hesed: Ben Sira's Pedagogy in Praise of the Fathers (Sir 44-50) (nieopublikowany doktorat obroniony na Uniwersytecie Kalifornijskim w Berkley w 1998 r.), s. 63; G. S a u e r, Studien zu Ben Sira, s. 94. 
wodu swej żony Sary, skłamał, mówiąc, że jest ona jego siostrą. Tylko dzięki nadprzyrodzonej interwencji Boga nie została ona pojęta przez faraona i Abimeleka za żonę. W obu przypadkach patriarcha został ukazany jako człowiek, który nie potrafił zaufać Bogu i, lękając się o własne życie, próbował po ludzku uniknąć grożącego mu niebezpieczeństwa. Aby uchronić się przed nim, posunął się do jawnego kłamstwa (por. Syr 20,2433). Tak czyniąc, okazał się człowiekiem małej wiary, który jest zdolny nawet skłamać, ${ }^{44}$ by ratować własne życie. Co więcej, w celu ratowania siebie, był on zdolny pozostawić swą żonę, która miała zrodzić mu zapowiedzianego potomka. ${ }^{45}$ Według badaczy, którzy odnoszą Syr 44,19b do Rdz 12,9-20 i 20,1-18, powyższe wydarzenia z życia Abrahama świadczą o tym, że jego postępowanie wobec pogan i własnej żony nie naruszyło jego czci i sławy. ${ }^{46}$

R. Petraglio i B.C. Gregory słusznie uważają, że stwierdzenie zawarte w Syr 44,19b nie odnosi się do wyżej wymienionych wydarzeń z życia patriarchy, lecz jest sądem ogólnym charakteryzującym całe życie Abrahama. ${ }^{47}$ Również P.C. Beentjes twierdzi podobnie. Zdaniem tego ostatniego badacza, po pierwsze, wyrażenie didonai mōmon en tē [i] doksē [i] w Księdze Mądrości Syracha ma znaczenie

43 Zob. J. S c h r e i n e r, Patriarchen im Lob der Väter (zu Sir 44), s. 439.

44 „The lie itself cannot be the stain; rather the stain must be the potential adultery between Sarah and Pharaon or Abimelech which was avoided when the men realized Sarah was Abraham's wife. While it was permissible for a man at that time to have more than one wife, it was important for a woman to have sexual relations with only one man. The reason for this was practical rather than ethical; the ability to prove the paternity, and therefore the legitimacy, of children. Because Abraham is praised as the ancestor of nations, particularly Israel, it is important to establish the legitimacy of his heirs"; T. R a s h B r o w n, Sinners, Idol-Worshippers and Fools among the Men of Hesed: Ben Sira's Pedagogy in Praise of the Fathers (Sir $44-50)$, s. 63.

45 Zob. R. P e t r a g 1 i o, Il libro che contamina le mani, s. 66-69.

46 „Gemeint ist, dass die Heiden (Pharao, Abimelech) die Ehre Abrahams nicht antasten durften"; R. S m e n d, Die Weisheit des Jesus Sirach erklärt, s. 423.

47 Zob. B.G. G r e g o r y, Abraham as the Jewish Ideal: Exegetical Traditions in Sirach 44:19-21, s. 68; R. P e t r a g 1 i o, Il libro che contamina le mani, s. 69. 
ogólne, a nie odnoszące się do konkretnego wydarzenia lub wydarzeń. Po wtóre, rzeczownik mōmos jest wątkiem, który przewija się przez całą księgę, i po trzecie, jest on odniesiony również do Salomona, a co za tym idzie nie może odnosić się jedynie do Rdz 12 i 20. W podsumowaniu swego wywodu poświęconego Syr 44,19b P.C. Beentjes stwierdza, że Syrach pragnął w tym stychu promować Abrahama jako wzór postępowania, więc jego treść musi mieć znaczenie ogólne - odnoszące się do całego życia patriarchy. ${ }^{48}$

Analizując przesłanie Syr 44,19b, powinniśmy zwrócić uwagę na słowa zawarte w Rdz 17,1b. Bóg wzywa w nich Abrama, aby „miał upodobanie w Bogu i był nieskazitelny" (euarestei enantion emou kai ginou amemptos). Być może Syrach w 44,19b chciał podkreślić, że Abraham wypełnił owo wezwanie i zrealizował je w sposób doskonały w swoim życiu.

Pozostałe wersety perykopy poświęconej Abrahamowi, tzn. 44,20-21, są rozwinięciem a zarazem wyjaśnieniem jej dwóch pierwszych stychów, które, jak wspomnieliśmy powyżej, niektórzy egzegeci uważają za nagłówek pochwały Abrahama. Tak więc Syr 44,19b, w którym mędrzec ogłosił moralno-religijną doskonałość Ojca Izraela, został rozwinięty w wersecie bezpośrednio po nim następującym, tj. 44,20. ${ }^{49}$ Zaś do Syr 44,19a, gdzie mowa jest o jego

48 Zob. P.C. B e e n t j e s, Ben Sira 44:19-23 - The Patriarchs Text, Tradition, Theology, s. 218. „In Abraham's case (44:19), he was perfectly faithful to God, a tradition found as early as a century following the return from exile (see Neh 9:7-8a). Working within this tradition, Ben Sira aimed to portray Abraham as the faithful Israelite par excellence"; B.G. G r e g o r y, Abraham as the Jewish Ideal: Exegetical Traditions in Sirach 44:19-21, s. 68.

49 Zob. M.C. P a $1 \mathrm{~m}$ i s a n o, Siracide, 418. „Ben Sira aimed to portray Abraham as the faithful Israelite par excellence. Yet it is not enough to see him simply as faithful in a general sense; rather, because of Ben Sira's Torah-consciousness, Abraham's life must be seen to comport with all aspects of the Torah. Only then can he be seen to be truly faithful to the covenant. Therefore, Ben Sira subsequently defines in what sense Abraham's glory remained unblemished: through his law-keeping and his trials, both of which have tremendous covenantal significance in the reflections of Second Temple Judaism"; B.G. G r e g o r y, Abraham as the 
potomstwie, powraca w końcowej części perykopy, tzn. w 44,21, tworząc w ten sposób ramy całej jednostki literackiej.

Doskonałość religijno-moralna Abrahama $(44,20)$

Pierwszy stych 44,20, który wyjaśnia nam, dlaczego Syrach uznał Abrahama za człowieka doskonałego z punktu widzenia moralno-religijnego, stwierdza, że patriarcha w swoim życiu ,zachowywał Prawo Najwyższego" (synetērēsen nomon hypsistou).$^{50} \mathrm{~W}$ greckiej wersji Księgi Mądrości Syracha rzeczownik nomos („prawo”) odnosi się wyłącznie do Prawa, które Mojżesz otrzymał od Boga na górze Synaj (zob. 45,5; por. 24,23). ${ }^{51} \mathrm{~W} 44,20$ a potwierdza to dopełnienie „Najwyższego" (hypsistou), które jednoznacznie określa prawo jako Prawo Boże - Torę (zob. Syr 9,15; 19,17; 23,23; 39,1; 42,2; 49,4; por. 41,8 i 46,14). Każdego czytającego 44,20a powinno zadziwić stwierdzenie zawarte w tym stychu, ponieważ rodzi się pytanie, jak Abraham, żyjąc według Biblii wiele wieków przed Mojżeszem i zawarciem przymierza na Synaju, mógł zachowywać w swym życiu wynikające z nich przepisy i nakazy. Na jakiej podstawie i w jakim celu Syrach retrospektywnie przypisał Abrahamowi przestrzeganie Prawa, które zostało ogłoszone dopiero wiele lat po jego śmierci? G. Sauer udziela na powyższe pytania najprostszej z możliwych odpowiedzi, co nie oznacza, że jest ona właściwa. Jego zdaniem, wypowiedź mędrca w Syr 44,20a jest anachronizmem. ${ }^{52}$ T. Rash Brown sprzeciwia się tej interpretacji. Uważa ona, że w 44,20a Abraham jest raczej chwalony jako posłuszny Bogu w znaczeniu ogólnym i całościowym niż

Jewish Ideal: Exegetical Traditions in Sirach 44:19-21, s. 68-69; por. G. S a u e r, Studien zu Ben Sira, s. 94.

50 Zob. B.G. G r e g o r y, Abraham as the Jewish Ideal: Exegetical Traditions in Sirach 44:19-21, s. 69.

${ }^{51}$ Zob. R.T. S i e b e n e c k, May Their Bones Return to Life! - Sirarch's Praise of the Fathers, CBQ 21/1959, s. 423; J.G. S n a it h, Ecclesiasticus or The Wisdom of Jesus Son of Sirach, s. 219.

${ }_{52}$ Zob. G. S a u e r, Jesus Sirach/Ben Sira, s. 305; t e n ż e, Studien zu Ben Sira, s. 94-95. 
w odniesieniu do Prawa. ${ }^{53}$ T.R. Lee podkreśla, że Syrach w Pochwale Ojców uwydatnia nie posłuszeństwo wobec Boga, lub jego brak, całego Izraela, lecz poszczególnych osób. ${ }^{54}$ Jego zdaniem właśnie ta tendencja mogła być powodem przypisania Abrahamowi zachowywania Prawa w całym jego życiu.

Zdaniem wielu badaczy Księgi Mądrości Syracha, w Syr 44,20a można dostrzec aluzję do Rdz 17 i 22 oraz Rdz 12,1-4; 15,1-6 i 26,5.5 Zwłaszcza ten ostatni z wymienionych tekstów jest bardzo wymowny: „Abraham był mi posłuszny - przestrzegał tego, co mu poleciłem: moich nakazów, praw [ta dikaiomata mou] i pouczeń". ${ }^{56}$ B.C. Gregory uważa, że właśnie tekst ten był bezpośrednim tłem, wyrażonej w Syr 44,20a, myśli na temat zachowywania Prawa przez Abrahama ${ }^{57}$ G. Pérez Rodríguez sądzi, że posłuszeństwo Abrahama, o którym mówi mędrzec w 44,20a, powinniśmy ograniczyć jedynie

53 Zob. T. R a s h B row n, Sinners, Idol-Worshippers and Fools among the Men of Hesed: Ben Sira's Pedagogy in Praise of the Fathers (Sir 44-50), s. 64. Jej opinię potwierdza R.T. Siebeneck: ,Whether he is thinking of the Mosaic Law or not makes little difference. (...) Abraham's obedience was sufficiently established and hence Sirach could name him a zealous observer of divine law"; R.T. S i e b e n e c k, May Their Bones Return to Life! - Sirarch's Praise of the Fathers, s. 423-424.

54 Zob. T.R. L e e, Studies in the Form of Sirach 44-50, s. 28.

55 Zob. B.G. G r e g o r y, Abraham as the Jewish Ideal: Exegetical Traditions in Sirach 44:19-21, s. 70-71; A.A. D i L e 11 a, Ben Sira's Praise of the Ancestors of Old (Sir 44-49): The History of Israel as Parenetic Apologetics, s. 160; R. P e t r a g 1 i o, Il libro che contamina le mani, s. 65; G. S a u e r, Studien zu Ben Sira, s. 95; T. R a s h B row n, Sinners, Idol-Worshippers and Fools among the Men of Hesed: Ben Sira's Pedagogy in Praise of the Fathers (Sir 44-50), s. 64; P.W. S k e h a n, A.A. D i L e 11 a, The Wisdom of Ben Sira, s. 505.

${ }_{56}$ Zob. J.L. K u g e 1, Traditions of the Bible: A Guide to the Bible as It Was at the Start of the Common Era, Harvard University Press, Cambridge 1998, s. 706; J.G. S n a i th, Ecclesiasticus or The Wisdom of Jesus Son of Sirach, s. 219; B.M. Z a p f f, Jesus Sirach 25 - 51, s. 322.

$57, \ldots$ linguistic connections show that both Ben Sira and his grandson were probably working with Gen 26:5 as the textual background for this understanding of Abraham"; B.G. G r e g o r y, Abraham as the Jewish Ideal: Exegetical Traditions in Sirach 44:19-21, s. 70. Twierdzenie Gregory'ego jest słuszne w odniesieniu do tekstu hebrajskiego Syr 44,21a. 
do poddania się przez patriarchę Bożemu nakazowi opuszczenia rodzinnego miasta. ${ }^{58}$

Zdaniem zaś wielu innych badaczy, źródeł wypowiedzi zawartej w Syr 44,20a należy upatrywać w tradycji teologicznej czasów Drugiej Świątyni. D. Dziadosz uważa, że przestrzeganie Prawa przez Abrahama jest pierwszą linią teologiczną charakteryzującą żydowskie tradycje o tym patriarsze. ${ }^{59} \mathrm{R}$. Petraglio stwierdza, że posłuszeństwo Abrahama było tematem znanym w tradycji judaistycznej, skoro zostaje wspomniane wprost w Hbr $11,8 .{ }^{60} \mathrm{G}$. Pérez Rodríguez przywołuje poglądy niektórych rabinów, którzy uważali, że Abraham poznał Prawo Mojżeszowe w wizji, o której mówi Rdz 15. ${ }^{61}$ P.C. Beentjes twierdzi zaś, że to nie tradycja judaistyczna wpłynęła na ukazanie Abrahama jako ideału zachowywania Prawa, lecz wręcz przeciwnie, to właśnie z Syr 44,20a biorą swoje wyobrażenia na ten temat późniejsze dzieła pisarzy żydowskich. ${ }^{62}$ Opinię tę potwierdza B.C. Gregory, który bardzo szczegółowo i szeroko przedstawia tradycje wczesnojudaistyczne, które mówią o posłuszeństwie Abrahama (np. Miszna m. Qidd. 14; Jub. 6, 18-19 i inne ${ }^{63}$ ). Niektóre z nich utrzymywały nawet, że patriarcha znał pełną formę spisanego Prawa. ${ }^{64}$ Kwestia wzajemnych relacji Syr 44,20a do tradycji

58 Zob. G. Pére z Rodríg u e z, Eclesiástico, s. 1274.

59 Zob. D. D z i a d o s z, Tak było na poczatku... Izrael opowiada swoje dzieje. Literacka i teologiczna analiza wiodących tradycji Księgi Rodzaju, Wydawnictwo Archidiecezji Przemyskiej, Przemyśl 2011, s. 321.

${ }^{60}$ Zob. R. P e t r a g 1 i o, Il libro che contamina le mani, s. 65.

${ }_{61}$ Zob. G. Pér e z R od ríg u e z, Eclesiástico, s. 1274, przyp. 15.

${ }^{62}$ Zob. P.C. B e e n t j e s, Ben Sira 44:19-23 - The Patriarchs Text, Tradition, Theology, s. 219.

63 Zob. N.L. C a lve r t, Abraham, s. 2; D. D z i a d o s z, Tak było na poczatku, s. 324 D.S. R u s s e 11, The Old Testament Pseudepigrapha. Patriarchs \& Prophets in Early Judaism, SCM, Philadelphia 1987, s. 74-75; B.M. Z a p ff, Jesus Sirach 25 - 51, s. 322.

${ }^{64}$ Zob. B.G. G r e g o r y, Abraham as the Jewish Ideal: Exegetical Traditions in Sirach 44:19-21, s. 71-73. Podsumowując swą prezentację tradycji dotyczących zachowywania przez Abrahama Prawa, uczony ten pisze: „From the preceding survey it may be seen that Ben Sira's inference from Gen 26:5 that Abraham kept 
judaistycznych, mówiących o zachowywaniu przez Abrahama Prawa, wymaga dalszych dogłębnych analiz, byśmy mogli stwierdzić, kto od kogo zaczerpnął ową ideę odnoszącą się do patriarchy.

K. Kowalik ujmuje przesłanie Syr 44,20a w inny sposób. Łączy on zachowywanie Prawa przez Abrahama z kwestią dotyczącą jego potomstwa: „W takim kontekście ojcostwo Abrahama nabiera również nowego znaczenia. Nie niesie ono ze sobą wymiaru jedynie fizycznego - potomstwo Abrahama to jedynie ci, którzy są z nim związani przez więzy krwi. Syrach celowo wyakcentowuje wierność Abrahama przymierzu, a precyzyjniej mówiąc «Prawu Najwyższego» $(44,20)$. A przecież to Prawo otrzymał dopiero Mojżesz na Synaju. Trudno przypuszczać, by tak istotna kwestia została przez autora księgi wprowadzona w sposób przypadkowy. Wydaje się raczej, że chce on pokazać, iż Abraham rodzi poszczególne pokolenia przez swoją wierność. Jego synami stają się ci, którzy przestrzegają przekazanego im przez Torę Prawa i są mu wierni w swoim życiu". ${ }^{65}$

Podobnie uważa P.C. Beentjes. Jego zdaniem, przypisanie przestrzegania Prawa Abrahamowi miało na celu zwrócenie uwagi czytelników i uwydatnienie idei, że zachowywanie Tory jest warunkiem koniecznym do wejścia i zachowania przymierza (zob. stych następny 44,20b). ${ }^{66}$

Chcielibyśmy jednak zwrócić uwagę na inny argument, który można by określić jako wewnętrzny, tzn. odwołujący się jedynie do samego dzieła Syracha, bez nawiązywania do współczesnych mu

the law comes in the early stages of an elaborately developed tradition during the Second Temple period (and beyond). Unfortunately, the brevity of his remark makes it difficult to locate him among the specific variations on this theme. This is understandable, however, since Ben Sira stands at beginning of this tradition, a tradition of halakic exegesis that viewed Abraham as a keeper of the legal Torah. One will notice that Ben Sira, writing during the earliest stages of this tradition, has incorporated an inchoate piece of halakic exegesis into his understanding of Abraham"; tamże, s. 72-73.

${ }^{65}$ K.P. K o w a 1 i k, Postać Abrahama w świetle Księgi Syracha, s. 426.

${ }_{66}$ Zob. P.C. B e e n t j e s, Ben Sira 44:19-23 - The Patriarchs Text, Tradition, Theology, s. 218. 
poglądów wczesnego judaizmu na temat życia Abrahama. W tym celu powinniśmy skupić się na słowach, które są zapisane w 44,20a i na ich szerszym (obejmującym całą treść Księgi Mądrości Syracha) znaczeniu teologiczno-mądrościowym. Czasownik syntēreō („strzec”, „ochraniać”, „bronić”, „zachowywać”) w greckiej wersji dzieła mędrca z Jerozolimy odgrywa bardzo ważną rolę, ponieważ odnosi się do jednej z najważniejszych postaw mędrców i ludzi pragnących zdobyć mądrość. ${ }^{67}$ Potwierdza to Syr 2,15: „Ci, którzy boją się Pana, nie będą nieposłuszni słowom Jego, ci zaś, którzy kochają Go, będą strzegli [syntērēsousin] dróg Jego". Zachowywanie nakazów Bożych jest więc wyrazem miłości do Boga. Ponadto w wersecie tym, zbudowanym na zasadzie paralelizmu synonimicznego, przestrzeganie dróg Pana jest synonimem posłuszeństwa Bogu. W 6,26 mędrzec wzywa swych uczniów, aby zbliżyli się do mądrości i „z całej ich mocy strzegli jej dróg" (en hole [i] dynamei sou syntērēson tas hodous autēs). ${ }^{68}$ Syr 15,15 mówi, że zachowanie przykazań jest możliwe, a ten, komu to się uda, pozyska sobie upodobanie Boga. W 35,1 spotykamy podobną syntagmę do tej, która występuje w 44,20a (ho syntērōn nomon). Werset ten stwierdza, że ten, kto zachowuje Prawo, mnoży ofiary, tzn. zachowywanie Tory prowadzi do intensywnego życia kultycznego, a co za tym idzie - religijnego. W 37,12 Syrach zachęca swego ucznia, aby przebywał z ludźmi pobożnymi, tzn. takimi, którzy przestrzegają przykazań. Ten, kto pragnie zdobyć mądrość, będzie badał Prawo, ale będzie też zachowywał opowiadania sławnych ludzi (zob. 39,2). ${ }^{69}$ Zaś w 41,14 mędrzec wzywa swych uczniów, aby, jeśli chcą zdobyć mądrość, zachowywali jego naukę/formację. Ważną umiejętnością w życiu człowieka mądrego jest przestrzeganie odpowiedniego czasu, by nie sprowadzić na siebie jakichś nieprzyjemności (zob.

${ }_{67}$ Zob. A. P i w o w a r, Zdobycie mądrości wedtug Syracha (Syr 6,18-37), cz. II: Poddanie się mądrości i jego skutki (Syr 6,23-31), Biblical Annals 5(2015) nr 2, s. 332-333.

68 Zob. tamże, s. 331-333.

69 Zob. t e n ż e, Uczony w Piśmie - ideat człowieka poszukujacego madrości (Syr 38,24; 39,1-11), Biblical Annals 6(2016) nr 4, s. 550-553. 
4,20 i 27,12). Jak wynika z powyższej analizy, postawa, którą wyraża czasownik syntēreō, jest jedną z najważniejszych w nauczaniu Syracha, ponieważ bez niej nie można osiągnąć mądrości. W 44,20a doniosłość tej postawy uwydatnia dopełnienie bliższe, tzn. przedmiot, którego ona dotyczy, a którym w tym przypadku jest Prawo Najwyższego (nomos ${ }^{70}$ hypsistou). ${ }^{71} \mathrm{I}$ tu dotykamy jednego z najbardziej istotnych punktów nauczania mędrca. Ci, którzy kochają Boga, zostaną napełnieni Prawem (zob. 2,16). W 9,15 Syrach wzywa swego ucznia, aby każda jego rozmowa dotyczyła Prawa. Mędrzec stwierdza, że człowiek znający Prawo zdobędzie mądrość $\left(15,1^{72}\right)$. Odnotowuje również, że Prawo jest podstawą życia Izraela (zob. 17,11). W 24,23 jednoznacznie utożsamia wypełnianie Prawa z mądrością, a w 19,20 łączy je z bojaźnią Bożą (por. 21,11). Ten, kto szuka Prawa i zabiega o nie w swym życiu, zostanie nim wypełniony (zob. 32,15), zaś ten, kto ufa Prawu i wierzy w nie, będzie zachowywał przykazania (zob. 32,24). Człowiek mądry nie będzie nienawidził Prawa (zob. 33,2), lecz będzie je rozważał (zob. 39,173) i zaufa mu (zob. 33,3). Prawo przymierza Pana jest podstawą do chlubienia się (zob. 39,874) i nie należy się go wstydzić (zob. 42,2). Bezbożni porzucają Torę, co sprowadza na nich nieszczęścia (zob. 41,8). Prawo wraz z przymierzem otrzymał Mojżesz (zob. 45,5), ono ma oświecać i pouczać naród wybrany (zob. $45,17)$. Ponadto ma ono być gwarantem sprawiedliwości i podstawą sądzenia ludzi (zob. 46,14). Niestety, poza Dawidem, Ezechiaszem i Jozjaszem, wszyscy królowie porzucili Prawo i nie zachowywali go (zob. 49,4). W zakończeniu swej księgi Syrach stwierdza, że osiągnął

70 Na temat oddania tekstu hebrajskiego przy użyciu vó $\mu$ o $\varsigma$ w greckiej wersji Syr 44,20a zob. B.G. G r e g o r y, Abraham as the Jewish Ideal: Exegetical Traditions in Sirach 44:19-21, s. 69; R. P e t r a g 1 i o, Il libro che contamina le mani, s. 72-73.

${ }^{71}$ Zob. A. P i w ow a r, Mędrzec - ideał człowieka poszukującego mądrości (Syr 14,20 - 15,10), cz. II: Działanie mądrości (Syr 15,1-10), Biblical Annals 6(2016) nr 3, s. 365-366.

72 Zob. tamże, s. 359-370.

73 Zob. t e n ż e, Uczony w Piśmie - ideat człowieka poszukującego mąrości (Syr 38,24; 39,1-11), s. 543-550.

74 Zob. tamże, s. 557-558. 
mądrość, bo w swej drodze prowadzącej do jej zdobycia, sam usiłował zawsze zachowywać Prawo (zob. 51,1975). W nauczaniu mędrca Prawo zajmuje więc bardzo ważne (kluczowe) miejsce. Nie tylko utożsamia on je z mądrością, ale jednoznacznie stwierdza, że przestrzeganie jego przepisów i zachowywanie go w życiu codziennym jest wymogiem koniecznym do osiągnięcia mądrości przez człowieka.

Powracając do Syr 44,20a, możemy poddać pod rozwagę myśl, że być może tekst grecki, mówiąc o zachowywaniu przez Abrahama Prawa, pragnął ukazać go jako człowieka, który zdobył mądrość i dzięki temu stał się pierwszym spośród grona mędrców Izraela (podobnie uważa także R. Petraglio ${ }^{76}$ ). Co prawda, jeśli nasza interpretacja jest słuszna, rodzi się pytanie, dlaczego prawda ta nie została stwierdzona wprost, a jedynie wyrażona w sposób tak bardzo ukryty i niejasny. Być może intencją tłumacza - przyznajmy, wyrażoną w sposób dość skomplikowany i ukryty - było pragnienie, aby wyrazić prawdę - i potwierdzić ją na przykładzie życia Abrahama, ojca całego Izraela - o ścisłej łączności między zachowywaniem i przestrzeganiem Prawa, a zdobyciem mądrości, które nie jest nieosiągalne dla człowieka. Dzięki temu praojciec narodu wybranego i wielu innych ludów stałby się ideałem mędrca i przykładem dla wszystkich, którzy pragną zdobyć mądrość.

$\mathrm{Z}$ całą pewnością $\mathrm{w} 44,20$ a powinniśmy dostrzec przesłanie apologetyczno-parenetyczne skierowane przez Syracha do ludzi mu

75 Zob. te n że, Dwie drogi prowadzące do odnalezienia mądrości wedtug Syracha. Analiza egzegetyczno-teologiczna Syr 51,13-30, Biblical Annals 4(2014) nr 1, s. 70-71.

76 „La scelta di nomos, cioè legge, nella traduzione di Ben Sira è molto interessante. Bisogna sapere che questa traduzione greca avviene in un clima di dialogo con il mondo e la cultura greca. In questo clima il traduttore in sostnanza tende a 'presentare la legge come vera sapienza e la sua osservanza come la vera ragione. (...) Dunque l'idea è quella della legge come fonte di saggezza, saggezza alla quale si può ancorare tutta la propria vita. Probabilmente è questa stessa idea che sorregge $\mathrm{Si} 44,20^{\circ}$ : Abramo globalmente nella sua vita (...) si è affidato non a un singolo precetto di Dio bensì a Dio come guida, come saggezza della sua vita; ha osservato questa guida che era Dio stesso e la sua parola"; R. P e t r a g 1 i o, Il libro che contamina le mani, s. 73. 
współczesnych. ${ }^{77}$ Przypisując Abrahamowi zachowywania Prawa, zapewne chciał on zachęcić ich do przestrzegania i nie porzucania go, czego domagała się kultura hellenistyczna, która szerzyła się i przyciągała do siebie wielu Izraelitów w czasach współczesnych mędrcowi (wymiar parenetyczny). Równocześnie Syrach chciał bronić Prawa i ukazać jego ogromną rolę w życiu każdego wierzącego Żyda. Skoro Abraham, czyli ktoś tak ważny dla narodu, zachowywał je i wypełniał jego przepisy, to znaczy, że jest ono również dzisiaj nieodzowne i konieczne w życiu każdego człowieka, który mieni się mianem Izraelity - potomka Abrahama (wymiar apologetyczny). ${ }^{78}$

Syr 44,20b zawiera drugi argument przemawiający, zdaniem mędrca, za moralną doskonałością Abrahama. Możemy dopatrzeć się w nim także logicznej z punktu widzenia religijno-teologicznego konsekwencji postawy, którą Syrach wyraził w 44,20a.${ }^{79}$ Ponieważ patriarcha przestrzegał Prawa (w. 20a), dlatego też był on „w przymierzu z Bogiem" (egeneto en diathēkē [i] met' autou; w. 20b ${ }^{80}$ ). Może zdziwić fakt, że Syrach „odwraca” kolejność przyczynowo-skutkową odnoszącą się do przymierza i zachowywania Prawa. Na podstawie przymierza synajskiego powinniśmy ująć ją w kolejności odwrotnej, tzn. najpierw człowiek wchodzi w przymierze z Bogiem, a skutkiem tego jest wypełnianie Prawa, jako wyraz trwania w relacji z Panem określonej za pomocą przymierza. Mędrzec najpierw jednak powiedział, że Abraham zachowywał i wypełniał w swoim życiu Prawo,

77 Zob. D. D z i a d o s z, Tak było na poczatku, s. 326; J. S c h r e i n e r, Patriarchen im Lob der Väter (zu Sir 44), s. 439.

78 Zob. T. M a e r te n s, L'Éloge des Pères, s. 45-46.

79 Zob. A.A. D i L e 11 a, Ben Sira's Praise of the Ancestors of Old (Sir 44-49): The History of Israel as Parenetic Apologetics, s. 160.

${ }^{80}$ Tekst hebr. Syr 44,20b mówi: „Wszedł [Abraham - przyp. autora] w przymierze z Nim"; zob. P.C. B e e n j e s, Ben Sira 44:19-23 - The Patriarchs Text, Tradition, Theology, s. 219; C. M o p s i k, La Sagesse de ben Sira, s. 279; G. S a u e r, Studien zu Ben Sira, s. 95. P.C. Beentjes zwraca uwagę na niezwykłą myśl wyrażoną w tym stychu. To nie Bóg zawiera przymierze z Abrahamem, lecz przeciwnie, to patriarcha zawiera przymierze z Nim. Inicjatywa nie pochodzi więc od Boga lecz od Abrahama; P.C. B e e n t j e s, Ben Sira 44:19-23 - The Patriarchs Text, Tradition, Theology, s. 219; por. T. M a e r t e n s, L'Éloge des Pères, s. 51. 
czego następstwem było przymierze, które Bóg zawarł z nim. Być może uczynił tak, aby przymierze umieścić w centrum Syr 44,20. Powinniśmy bowiem zwrócić naszą uwagę na fakt, że tekst Syr 44,20 jest oparty na chiazmie:

a: $\quad$ strzeżenie Prawa - w. 20a

b: $\quad$ przymierze - w. $20 \mathrm{~b}$

b': przymierze - w. 20c

a': wierność nakazowi - w. 20d. ${ }^{81}$

$Z$ całą pewnością w Syr 44,20b należy dostrzec odniesienie do Rdz 15 i Rdz 17 (A.A. Di Lella i B.M. Zapff Syr 44,20b odnoszą jedynie do Rdz 17 z powodu obrzezania, o którym mowa jest w następnym stychu; ${ }^{82}$ zaś G. Sauer 44,20b łączy z Rdz 15, a 44,22c z Rdz 17). ${ }^{83} \mathrm{Rdz}$ 15 koncentruje się na obietnicy licznego potomstwa, Rdz 17 powtarza ją i dodaje do niej otrzymanie kraju, w którym przebywa Abram, oraz zapowiedź narodzin Izaaka jako dziedzica patriarchy. W obu tekstach zostało stwierdzone, że Bóg zawarł przymierze z Abrahamem (zob. Rdz 15,18; 17,2.4.7). W drugim stychu 44,20 mędrzec nie mówi o zawarciu przymierza, lecz stwierdza w sposób ogólny, że ojciec narodu „był w przymierzu” z Panem (egeneto en diathēkē [i] met’ autou). Syrach nie koncentruje się na momencie zawarcia przymierza, lecz stwierdza, że patriarcha wytrwał do końca swego życia w tej wyjątkowej relacji z Bogiem, która została wyrażona za pośrednictwem przymierza. Syr 44,20b nie odnosi się więc do konkretnego momentu w życiu Abrahama (zawarcie przymierza), lecz jest bardzo ogólnym podsumowaniem całego jego życia, którego głównym kryterium jest wierność przymierzu. Formę aorystu (egeneto) powinniśmy więc interpretować jako aoristus complexivus.

81 Por. B.G. G r e g o r y, Abraham as the Jewish Ideal: Exegetical Traditions in Sirach 44:19-21, s. 77.

${ }^{82}$ Zob. P.W. S ke ha n, A.A. D i L e 11 a, The Wisdom of Ben Sira, s. 505; B.M. Z a p ff, Jesus Sirach 25 - 51, s. 322.

83 Zob. G. S a u e r, Jesus Sirach/Ben Sira, s. 305; zob. R. P e t r a g 1 i o Il libro che contamina le mani, s. 65; G. S a u e r, Studien zu Ben Sira, s. 95. 
Może nas dziwić to, że Syrach najpierw wypowiada sąd ogólny odnoszący się do przymierza, jakie Bóg zawarł z Abrahamem, a dopiero później rozwija temat tegoż przymierza ${ }^{84}$ ale jeśli odwołamy się do początku całej perykopy poświęconej Abrahamowi, to nie powinno nas to zdumiewać. Podobnie jak 44,19 jest podsumowaniem całego życia patriarchy (zob. powyżej), tak samo mędrzec, wprowadzając temat przymierza w życiu ojca narodu wybranego, rozpoczyna ten wątek od stwierdzenia o charakterze ogólnego i całościowego podsumowania odnoszącego się do tego, w jaki sposób Abraham (z)realizował owo przymierze podczas swego życia. Słowa „był w przymierzu” z Bogiem przekazują nam bardzo ważną wiadomość, że wytrwał on przy Panu i nigdy nie przeciwstawił się Mu ani nie odszedł od Niego - nie porzucił Go, ani nie sprzeniewierzył się Mu. Słowa te powinniśmy odnieść do Syr 44,19b, które mówiły o moralno-religijnej doskonałości Abrahama. Syr 44,20b potwierdza powyższe oświadczenie mędrca i ukazuje, na czym polegała owa nieskazitelność życia. Bycie doskonałym oznacza wytrwanie w przymierzu oraz konsekwentne i nieustanne realizowanie jego postanowień. W dwóch innych miejscach swego dzieła Syrach wzywa uczniów do takiej postawy. W 11,20 apeluje do nich, aby trwali w przymierzu, byli mu oddani i wypełniali je do końca ich życia. W podobny sposób zachęca ich w 28,7, aby pamiętali o przykazaniach i przymierzu. Syr 44,20b jest dowodem na to, że człowiek może zrealizować te wezwania w swoim życiu.

Kolejny stych (Syr 44,20c) również odnosi się do przymierza. Rozwija on i precyzuje przesłanie poprzedniego (44,20b). Odnosi się już bezpośrednio i jednoznacznie do przymierza, o którym mowa jest w Rdz 17. Wskazuje na to odwołanie do obrzezania, które było jego znakiem (zob. Rdz 17,10-14). Rdz 17,13 przymierze to określa mianem ,przymierza w odniesieniu do waszego ciała” (Rdz 17,13:

84 Powyższej trudności nie dostrzegamy w tekście hebrajskim, który mówi o zawarciu przymierza, a nie trwaniu Abrahama w przymierzu; zob. P.C. B e e n t j e s, Ben Sira 44:19-23 - The Patriarchs Text, Tradition, Theology, s. 219; C. M o p s i k, La Sagesse de ben Sira, s. 279. 
he diathēkè mou epi tēs sarkos hymōn). Obrzezanie stało się więc nie tylko znakiem, ale, co więcej, głównym wymaganiem tegoż przymierza i poniekąd jego istotą (por. Rdz 17,14: „Nieobrzezany /.../, taki człowiek niech będzie usunięty ze swej społeczności; zerwał on bowiem przymierze ze Mną"). ${ }^{85}$ Rdz 17,24.26 mówi, że Abraham zrealizował natychmiast powyższe wymaganie przymierza - został obrzezany on sam, jego syn Izmael oraz wszyscy jego domownicy. Skoro obrzezanie było głównym wymogiem przymierza, jakie Bóg zawarł z Abrahamem, i skoro poddał się mu on oraz wszyscy podlegli mu mężczyźni, to znaczy, że patriarcha wypełnił przymierze (zob. 44,20b).

Syrach, mówiąc o przymierzu, koncentruje się nieprzypadkowo na obrzezaniu. Syr 44,20c zawiera bardzo wyraźne odniesienie do czasów, w których żył mędrzec. Pod wpływem kultury hellenistycznej wielu Żydów porzucało ten wymóg religijny (zob. 1Mch 1,15), ${ }^{86}$ przez co wykluczali się ze wspólnoty ludzi wierzących w Boga. Wzmianka o obrzezaniu w pochwale Abrahama ma uświadomić współczesnym mędrcowi z Jerozolimy Izraelitom wagę tego wymogu religijnego i stanowić zachętę, by nie odwracali się oni od niego i nie porzucali w ten sposób wiary ojców. K.P. Kowalik uważa, że „przedstawiona przez Syracha historia Abrahama pragnie w nowym świetle uka-

85 Zob. R.G. Ha 11, Circumcision, w: D.N. Fre ed m a n (red.), The Anchor Bible Dictionary, t. I, s. 1027; J. M u r p hy-O 'C o n n o r, Circoncisione, w: R. P e n n a, G. P e r e g o, G. R a v a s i (red.), Temi teologici della Bibbia, s. 168-169; G. Pér e z R o dríg u e z, Eclesiástico, s. 1275; L. R y k e n, J.C. W i 1 h o it, T. L o n g m a n III, Słownik symboliki biblijnej, s. 616-617; R. d e V a u x, Instytucje Starego Testamentu, Pallottinum, Poznań 2004, t. I, s. 58; C. W i é n e r, Obrzezanie, w: X. L é o n - D u fo u r (red.) Stownik teologii biblijnej, s. 597; P.R. W i 11 i a m s o n, Circumcision, w: T.D. A 1 e x a n d e r, D.W. B a k e r (red.), Dictionary of the Old Testament: Pentateuch, InterVarsity Press, Downers Grove-Leicester 2003, s. 123-125.

${ }^{86}$ Zob. R.G. H a 11, Circumcision, s. 1027-1029; K.P. K ow a l i k, Postać Abrahama $w$ świetle Księgi Syracha, s. 427; T. M a e r te n s, L'Éloge des Pères, s. 50-51; J. M u r p h y - O ' C o n n o r, Circoncisione, s. 170-171; T. R a s h B row n, Sinners, Idol-Worshippers and Fools among the Men of Hesed: Ben Sira's Pedagogy in Praise of the Fathers (Sir 44-50), s. 65; G. S a u e r, Studien zu Ben Sira, s. 96; R. d e V a u x, Instytucje Starego Testamentu, s. 58. 
zać ojcostwo patriarchy, sprowadzając je do dwóch zasadniczych elementów: wypełniania Prawa i zachowania znaku obrzezania" ${ }^{87}$ B.C. Gregory sądzi, że obrzezanie, o którym jest mowa w Syr 44,20c, należy łączyć z zachowywaniem przez Abrahama Prawa (zob. 44,20a; podobnie uważają również G. Sauer i J. Schreiner ${ }^{88}$ ). Na tej podstawie dochodzi on do wniosku, że przymierze i posłuszeństwo są nierozerwalnie ze sobą związane, a obrzezanie jest tym, co należy zachowywać i czego należy przestrzegać, czyli łączy je w jedno. ${ }^{89}$

Ostatnią postawą Abrahama wymienioną przez Syracha w 44,20d, która wyjaśnia na czym polegała moralno-religijna doskonałość patriarchy, jest „wytrwanie w próbie” (en peirasmō[i] heurethe pistos). Powinniśmy zwrócić uwagę na powtórne (zob. 44,19b) użycie formy aorystu strony biernej czasownika heuriskō w tym stychu. Tworzy ona inkluzję pierwszej sekcji analizowanej przez nas perykopy (tj. 44,19b-20), która koncentruje się na postawie Abrahama wobec Boga i Jego nakazów. Interesujące i bardzo wymowne jest w tekście greckim Księgi Mądrości Syracha użycie tej formy czasownikowej (heurethē). Poza 44,19b i 44,20d spotykamy ją jeszcze dwa razy. W 31,8a została ona odniesiona do człowieka bogatego, który jeśli został znaleziony „bez winy” (heurethe amōmos) i „,nie gonił za bogactwem" (hos opisō chrysiou ouk eporeuthē) jest błogosławiony/ szczęśliwy (makarios). Zaś w Syr 44,17a przy jej użyciu został przedstawiony Noe, który był „doskonale sprawiedliwy” (Nōe heurethe teleios dikaios). Na tej podstawie możemy stwierdzić, że heurethe zawsze odnosi się do pozytywnej postawy moralno-religijną człowieka względem Boga, podobnie jak w przypadku Abrahama.

W nauczaniu Syracha sama próba i poddanie jej kogoś odgrywa bardzo ważną rolę. Są one praktycznym i konkretnym sprawdzianem,

87 K.P. K o w a 1 i k, Postać Abrahama w świetle Księgi Syracha, s. 427.

${ }_{88}$ Zob. G. S a u e r, Studien zu Ben Sira, s. 95-96; J. S c h r e i n e r, Patriarchen im Lob der Väter (zu Sir 44), s. 439.

89 Zob. B.G. G r e g o r y, Abraham as the Jewish Ideal: Exegetical Traditions in Sirach 44:19-21, s. 70. „20c bezieht sich nicht lediglich auf den Vorgang der Beschreibung, sondern kombiniert diesen mit einem geistigen Inhalt, dem Gesetz"; B.M. Z a p f f, Jesus Sirach $25-51$, s. 22. 
dzięki któremu możemy poznać prawdziwą wartość człowieka (zob. 27,5.7), np. przyjaciela (zob. Syr 6,7). Człowiek bojący się Pana zostanie poddany próbie, ale żadne zło go nie spotka, ponieważ zostanie wybawiony (zob. 33,1). Już na początku dzieła mędrzec kieruje do swego ucznia nader ważne ostrzeżenie: „Dziecko, jeśli zbliżyłbyś się do Pana, aby Mu służyć, przygotuj swą duszę na próbę" (teknon ei proserchē [i] douleuein kyriō[i] hetoimason tēn psychēn sou eis peirasmon). Doświadczenie jest nieodzownym etapem człowieka w drodze do Boga i ono ukazuje całą prawdę o nim. Również Abraham został poddany takiej próbie i okazał się wierny. Nie upadł, ale wytrwał przy Bogu.

Z całą pewnością możemy stwierdzić, że w Syr 44,20d mędrzec nawiązał do wydarzeń opisanych w Rdz 22,1-19, czyli żądania Boga, aby patriarcha ofiarował Mu swego syna, który został mu dany na podstawie obietnicy jako dziedzic i spadkobierca. ${ }^{90}$ Czasownik peiradzō („próbować”, „wystawiać na próbę”, „poddawać próbie”, „doświadczać”; zob. Rdz 22,1) i pochodzący od niego rzeczownik peirasmos (zob. Syr 44,20d) bezsprzecznie łączą oba teksty. ${ }^{91}$ Syrach podobnie jak we wcześniejszych stychach nie poświęca wydarzeniom, do których czyni aluzje w pochwale Abrahama, większej uwagi, tzn. nie opisuje ich dokładniej i nie wyjaśnia ich, podaje jedynie lakonicznie, w formie dość apodyktycznej swoją interpretację tych zdarzeń w postaci krótkiego i jednoznacznego osądu na temat patriarchy.

90 Zob. P.C. B e e n t j e s, Ben Sira 44:19-23 - The Patriarchs Text, Tradition, Theology, s. 221; B.G. G r e g o r y, Abraham as the Jewish Ideal: Exegetical Traditions in Sirach 44:19-21, s. 73; T. M a e r t e n s, L'Éloge des Pères, s. 47; M.C. P a $1 \mathrm{~m}$ i s a n o, Siracide, s. 418; G. Pé r e z R o d ríg u e z, Eclesiástico, s. 1275; R. P e t r a g 1 i o, Il libro che contamina le mani, s. 65; J. S c h r e i n e r, Patriarchen im Lob der Väter (zu Sir 44), s. 439; P.W. S k e h a n, A.A. D i L e 11 a, The Wisdom of Ben Sira, s. 505; G. S a u e r, Jesus Sirach/Ben Sira, s. 305; J.G. S n a it h, Ecclesiasticus or The Wisdom of Jesus Son of Sirach, s. 219; B.M. Z a p f f, Jesus Sirach 25 - 51, s. 322.

91 Zob. B.G. G r e g o r y, Abraham as the Jewish Ideal: Exegetical Traditions in Sirach 44:19-21, s. 73-74; R. P e t r a g 1 i o, Il libro che contamina le mani, s. 65. Por. T. R a s h B row n, Sinners, Idol-Worshippers and Fools among the Men of Hesed: Ben Sira's Pedagogy in Praise of the Fathers (Sir 44-50), s. 66. 
W ten sam sposób czyni również w 44,20d. Oświadcza krótko i syntetycznie: Abraham został poddany próbie i okazał się wierny. Jest to dość zdawkowe stwierdzenie, jeśli pamiętamy kogo (syna obietnicy) i czego (ofiarowanie go Bogu) dotyczyła powyższa próba. Mędrca nie interesuje ogromny dramatyzm doświadczenia, któremu został poddany patriarcha, dla niego liczy się jedynie jego wynik - to, że Abraham był posłuszny Bogu i był gotów wypełnić Jego polecenie. Najważniejsze jest to, że okazał się wiernym. ${ }^{92}$

Zdaniem G. Péreza Rodrígueza, gotowość do ofiarowania Izaaka na polecenie Boga była szczytowym punktem wiary i posłuszeństwa Abrahama Najwyższemu. ${ }^{93}$ B.C. Gregory uważa jednak, że w Syr 44,20d powinniśmy dostrzegać nie tylko aluzję do Rdz 22 (G. Sauer twierdzi, że Syr 44,20d należy odnieść jedynie do $\operatorname{Rdz} 22^{94}$ ), ale również do Rdz $15,6,{ }^{95}$ choć uczony ten uważa Syracha za twórcę idei wierności Abrahama w odniesieniu do ofiarowania Izaaka. ${ }^{96} \mathrm{~W}$ późniejszej tradycji judaistycznej, zwłaszcza w czasie zagrożenia wierności narodu wybranego swemu Bogu, Abraham był przywoływany jako przykład i ideał wierności (zob. 1Mch 2,52;97

92 „The 'trial motif' occurs several times elsewhere in the Book of Ben Sira. And one would expect Ben Sira to have elaborated such an important theological stream in this text on Abraham. It is more surprising, therefore, that the remainder of Sir 44:20d has no resemblance whatsoever with the famous text from Genesis 22"; P.C. B e e n t j e s, Ben Sira 44:19-23 - The Patriarchs Text, Tradition, Theology, s. 221.

93 Zob. G. Pére z R o d ríg u e z, Eclesiástico, s. 1275; por. B.G. G r e g o r y, Abraham as the Jewish Ideal: Exegetical Traditions in Sirach 44:19-21, s. 75.

94 Zob. G. S a u e r, Studien zu Ben Sira, s. 96.

95 Zob. B.G. G r e g o r y, Abraham as the Jewish Ideal: Exegetical Traditions in Sirach 44:19-21, s. 74-75.

96 Zob. tamie, s. 75.

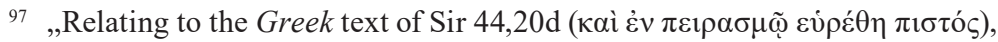
it can hardly be coincidental that exactly the same phrase is found in 1 Macc 2:52, where it refers to Abraham too. Since Ben Sira's grandson, the translator of the Hebrew Ben Sira text, and the author of 1 Maccabees must have been contemporaries, it is impossible to determine who adopted this phrase from whom. It looks 
Ne 9,8; ${ }^{98}$ Jub. 17,17-18; 19,8; por. Jk 2,21). ${ }^{99}$ P.C. Beentjes uważa, że bezpośrednim literackim tłem Syr 44,20d jest Ne 9,8, a nie Rdz 15,6. Jego zdaniem, przemawiają za tym argumenty literackie. ${ }^{100}$

B.M. Zapff podkreśla, że Syr 44,20d ma wyraźny charakter paranetyczny. W słowach tych Syrach, zdaniem tego niemieckiego egzegety, pragnął zachęcić Izraelitów, którzy doświadczali zagrażających ich religijno-narodowej tożsamości pokus, aby wytrwali przy Bogu na wzór Abrahama. ${ }^{101}$

Tak jak zauważyliśmy powyżej opis moralno-religijnej doskonałości Abrahama ma strukturę koncentryczną, w której centrum znajduje

like a kind of a topos which was in the air at that time"; P.C. B e e n t j e s, Ben Sira 44:19-23 - The Patriarchs Text, Tradition, Theology, s. 222.

98 „Interestingly, in Ezra's brief account of Israel's history in Nehemiah 9 he mentions only a few other incidents (besides being found faithful) in Abraham's life as significant: God's choosing of Abraham, his departure from Ur, his name change, and the covenant to give him the land. Absent from this account is any reference to Abraham's testing in Genesis 22. Rather, the reference to Abraham's faithfulness in Nehemiah most likely follows Gen 15:6"; B.G. G r e g o r y, Abraham as the Jewish Ideal: Exegetical Traditions in Sirach 44:19-21, s. 73-74. Por. J. S c h r e i n e r, Patriarchen im Lob der Väter (zu Sir 44), s. 439.

99 Zob. P.C. B e e n t j e s, Ben Sira 44:19-23 - The Patriarchs Text, Tradition, Theology, s. 221-222; D. D z i a d o s z, Tak było na poczatku, s. 323-324; B.G. G r e g o r y, Abraham as the Jewish Ideal: Exegetical Traditions in Sirach 44:19-21, s. 74-76; D.S. R u s s e 11, The Old Testament Pseudepigrapha, s. 74-75. G. Sauer twierdzi, że Syr 44,20d odwołuje się bardziej do tradycji judaistycznej mówiącej o wierności Abrahama w czasie próby, niż do tekstów biblijnych opisujących życie tego patriarchy; G. S a u e r, Studien zu Ben Sira, s. 96-97.

${ }^{100}$ Zob. P.C. B e e n t j e s, Ben Sira 44:19-23 - The Patriarchs Text, Tradition, Theology, s. 222-223.

${ }^{101}$ Zob. B.M. Z a p f f, Jesus Sirach 25 - 51, s. 322; por. T. M a e r t e n s, L'Éloge des Pères, s. 47. „Au moment où Ben Sira rédige son Eloge du patriarche pour inviter le peuple à faire son choix entre l'hellénisme tout humain et la fidélité à l'Alliance, il rappelle opportunément que ce choix n'est autre que celui d'Abraham lui-même, sacrifiant son fils selon la chair pour recouver un fils selon l'esprit et la promesse. (...) L'épreuve que Ben Sira contemple dans la vie d'Abraham doit avoir sa réplique et son prolongement en celle que le peuple juif se prépare à subir dans sa lutte contre l'hellénisme. Le rappel de la fidélité d'Abraham en des circonstances identiques sera le grand soutien de ceux qui se proclament ses fils"; tamże, s. 48-49. 
się przymierze. Dzięki zastosowaniu przez mędrca powyższej konstrukcji poetyckiej podkreślił on w przedstawionej przez siebie postawie moralno-religijnej Abrahama rolę przymierza z Bogiem w jego życiu. Ono znajdowało się w centrum jego postępowania i każdy jego czyn był mu podporządkowany. Skrajne stychy (44,19a i 44,20d) ukazują i specyfikują, w jaki sposób należy realizować przymierze we własnym życiu. Aby tego dokonać, trzeba zachowywać Prawo i być wiernym Najwyższemu oraz wytrwać przy Nim nawet w najtrudniejszych sytuacjach, w jakich może znaleźć się każdy człowiek.

\section{Skutki moralno-religijnej doskonałości Abrahama - obietnice dotyczące jego potomstwa $(44,21)$}

Doskonałość moralno-religijna Abrahama ogłoszona przez Syracha w Syr 44,19a-22d jest przyczyną i podstawą obietnic zawartych w Syr 44,21, które Bóg złożył patriarsze. ${ }^{102}$ Wyraźnie wskazuje na to rozpoczynająca Syr 44,21a syntagma dia touto („dlatego”, „z tego powodu”, ,ze względu na to"). ${ }^{103}$ Wyraża ona rację lub powód, dla którego coś się dokonuje lub wynika - istnieje. ${ }^{104}$ Przyczyną, która sprawiła, że Najwyższy udzielił patriarsze obietnic wyrażonych przez

102 „The faithfulness of Abraham mentioned in 44:20 is the implied foundation of the promises in 44:21, all which are dependent on the great redemptive events in Israel's history (e.g., the exodus). Already in Sirach the future blessing of Israel are contingent on Abraham's obedience, particularly that of his greatest trial in Genesis 22"; B.G. G r e g o r y, Abraham as the Jewish Ideal: Exegetical Traditions in Sirach 44:19-21, s. 76. Por. P.C. B e e n t j e s, Ben Sira 44:19-23 - The Patriarchs Text, Tradition, Theology, s. 222; G. P é r e z R o d r í g u e z, Eclesiástico, s. 1275; G. S a u e r, Jesus Sirach/Ben Sira, s. 305; t e n ż e, Studien zu Ben Sira, s. 97.

${ }^{103}$ Por. P.C. B e e n t j e s, Ben Sira 44:19-23 - The Patriarchs Text, Tradition, Theology, s. 222; B.G. G r e g o r y, Abraham as the Jewish Ideal: Exegetical Traditions in Sirach 44:19-21, s. 37.

${ }^{104}$ Zob. M.J. H a r r i s, Preposition and Theology in the Greek New Testament. An Essential Reference Resource for Exegesis, Zordevan, Grand Rapids 2012, s. 72 -76; R. P o p o w s k i, Wielki słownik grecko-polski Nowego Testamentu wydanie z petna lokalizacja greckich haset, kluczem polsko-greckim oraz indeksem form czasownikowych, „Vocatio”, Warszawa 20064, s. 125-126; A.T. R o b e r t s o n, 
mędrca w 44,21, jest jego postawa wobec Pana. M.C. Palmisano uważa, że Syr 44,21 precyzuje, na czym polega i w czym przejawia się chwała Abrahama. ${ }^{105}$ Ponadto twierdzi ona, że wielkość patriarchy, o której jest mowa w tym wersecie, nie opiera się na jego przymiotach osobistych, lecz jedynie na Bożych obietnicach. ${ }^{106}$

Syr 44,21 nawiązuje do Rdz 22,16-18. ${ }^{107}$ Gdy Bóg przekonał się, że Abraham jest $\mathrm{Mu}$ całkowicie posłuszny i był gotów złożyć $\mathrm{Mu}$ w ofierze swego syna Izaaka, z którym były związane obietnice licznego potomstwa (przyszłość jego rodu), przysiągł patriarsze, że będzie mu błogosławił i da mu potomstwo ,tak liczne jak gwiazdy na niebie i jak ziarnka piasku na wybrzeżu morza" ( $R d z 22,17$; por. Rdz 13,16; 15,5; 17,6; a także Rdz 28,14 ${ }^{108}$ ). Obiecał także pomyślność i szczęście dla jego potomstwa tak wielkie, że inne ludy będą go pragnąć (zob. Rdz 22,18; por. Rdz 26,409). W tekście tym mowa jest o niezwykłym rozmnożeniu potomków Abrahama (por. Syr 44,21cd), ale brakuje stwierdzenia o błogosławieństwie innych narodów za ich pośrednictwem, co wyraźnie stwierdza Syrach w Syr 44,21b, oraz o odziedziczeniu ziemi (por Syr 44,21e-g). O błogosławieństwie innych narodów, którego pośrednikiem będzie potomstwo Abrahama, mówi Rdz 12,2-3 oraz 28,14 (obietnica dana Jakubowi - potomkowi Abrahama), zaś o daniu rodowi patriarchy licznych ziem Rdz 15,18-21

A Grammar of the Greek New Testament in the Light of Historical Research, Broadman Press, Nashville 2010, s. 583-584.

${ }^{105}$ Zob. M.C. P a $1 \mathrm{~m}$ i s a n o, Siracide, s. 418.

106 Zob. tamże; G. S a u e r, Studien zu Ben Sira, s. 97.

107 Zob. P.C. B e e n t j e s, Ben Sira 44:19-23 - The Patriarchs Text, Tradition, Theology, s. 222; B.G. G r e g o r y, Abraham as the Jewish Ideal: Exegetical Traditions in Sirach 44:19-21, s. 78; P.W. S k e h a n, A.A. D i L e 11 a, The Wisdom of Ben Sira, s. 505; B.M. Z a p f f, Jesus Sirach 25 - 51, s. 323.

108 Zob. T. M a e r te n s, L'Éloge des Pères, s. 40.

109 Zob. P.C. B e e n t j e s, Ben Sira 44:19-23 - The Patriarchs Text, Tradition, Theology, s. 222-223; G. S a u e r, Studien zu Ben Sira, s. 97; J. S c h r e i n e r, Patriarchen im Lob der Väter (zu Sir 44), s. 439. 
i 17,8 (por. Rdz 13,15). ${ }^{110}$ Syrach w 44,21 nawiązuje do wszystkich tych tekstów i łączy je w jedną obietnicę, którą Bóg złożył Abrahamowi. ${ }^{111}$

\section{Potomstwo Abrahama nosicielem błogostawieństwa dla innych narodów (44,2lab)}

Z punktuwidzenia literackiego wydaje się, że Syr44,21a, a zwłaszcza słowa en horkō [i] estēsen autō[i] (dosł. ,,przysięgą/w przysiędze/z powodu przysięgi ustalił mu/dla niego"), nawiązują do greckiego tekstu Rdz 26,3b: stēsō ton horkon mou hon ōmosa Abraam tō[i] patri sou (,wypełnię przysięgę moją, którą przysiągłem Abrahamowi, ojcu twojemu/z powodu ojca twojego") - obietnicy złożonej Izaakowi. Podobieństwo powyższych dwóch tekstów jest uderzające i, zdaje się, nieprzypadkowe. R. Petraglio i B.M. Zapff sądzą, że obietnica, o której mowa w Syr 44,21a, jest odniesieniem i nawiązaniem także do $\operatorname{Rdz} 22,16 .{ }^{112}$

W uważnym czytelniku znającym tekst cyklu o Abrahamie może budzić pewne zdziwienie występowanie w Syr 44,21a rzeczownika horkos (,przysięga”), albowiem treść następujących po nim stychów (zwłaszcza 21c-g) odnosi się do przymierza, jakie Bóg zawarł z patriarchą. Dlaczego więc wnuk mędrca, tłumacząc dzieło swego dziadka, nie użył w tym miejscu słowa diathēkē (,przymierze”)? Nie uczynił tego, ponieważ treść dalszych stychów nie odnosi się tylko do przymierza Boga z patriarchą, ale również do innych tekstów, dlatego użycie słowa „przymierze” byłoby mylące i wprowadzałoby w błąd czytelnika. Obietnice bowiem są jedynie częścią przymierza, które Pan zawarł z Abrahamem, ale nie ograniczają się wyłącznie do niego.

${ }^{110}$ Zob. P.C. B e e n t j e s, Ben Sira 44:19-23 - The Patriarchs Text, Tradition, Theology, s. 223.

111 Zob. R. P e t r a g 1 i o, Il libro che contamina le mani, s. 65; G. S a u e r, Studien zu Ben Sira, s. 97. „After detailing Abraham's relationship with God, Ben Sira employs a series of biblical quotations and allusions"; B.G. G r e g o r y, Abraham as the Jewish Ideal: Exegetical Traditions in Sirach 44:19-21, s. 77.

${ }_{112}$ Zob. R. Pet r a g 1 i o, Il libro che contamina le mani, s. 65; B.M. Z a p f f Jesus Sirach 25 - 51, s. 323. 
Przywołanie obietnic, które Bóg złożył patriarsze, tekst grecki rozpoczyna od stwierdzenia, że potomkowie jego będą ,pośrednikami błogosławieństwa Bożego dla innych narodów" (eneulogèthēnai ethnē en spermati autou $)^{113}$ - będą one błogosławione za pośrednictwem potomków Abrahama (en spermati autou możemy interpretować jako dativus instrumentalis lub causae - „Z powodu potomstwa jego"). $\mathrm{Z}$ jednej strony możemy powiedzieć, że Syr 44,21b odwołuje się do pierwszej złożonej ojcu narodu wybranego obietnicy (zob. Rdz 12,2-3; ${ }^{114}$ M.B. Zapff uważa zaś, że drugi stych w. 21 czyni aluzję do Rdz $\left.22,18^{115}\right)$, z drugiej zaś strony powinniśmy zauważyć, że przyrzeczenie to zakłada posiadanie licznego potomstwa, co Bóg, według kolejności przyjętej przez mędrca z Jerozolimy, czyni dopiero na drugim miejscu (44,21cd). Wydaje się, że sekwencja obietnic złożonych Abrahamowi wyrażonych przez Syracha stara się podkreślić miejsce Izraela wśród wszystkich ludów całej ziemi. Nie jest to naród jak inne, ale jest on nosicielem i przekazicielem - pośrednikiem Bożego błogosławieństwa. Jeśli nasza interpretacja jest słuszna i prawidłowa, to powinniśmy dostrzec w niej aspekt apologetyczny zwrócony do współczesnych mędrcowi Izraelitów. Nie muszą wstydzić się swego narodu i odczuwać niższości swej religii i kultury wobec hellenizmu, wręcz przeciwnie, powinni być z nich dumni, ponieważ dzięki nim inne ludy i narody otrzymują liczne łaski i dary od Stwórcy. ${ }^{116}$

113 P.C. Beentjes podkreśla, że moglibyśmy spodziewać się, że Syr 44,21b została zaczerpnięta $\mathrm{z}$ Rdz, ale tak nie jest. Myśl wyrażona w tym stychu jest nowością, czyli oryginalnym tworem Syrachowego ujęcia postaci Abrahama; zob. P.C. B e e n t j e s, Ben Sira 44:19-23 - The Patriarchs Text, Tradition, Theology, s. 222.

${ }_{114}$ Zob. G. S a u e r, Jesus Sirach/Ben Sira, s. 305; t e n ż e, Studien zu Ben Sira, s. 97; J. S c h r e i n e r, Patriarchen im Lob der Väter (zu Sir 44), s. 439; B.M. Z a p f f, Jesus Sirach 25 - 51, s. 323.

115 Zob. tamże.

116 „Ben Sira zögert nicht, die Berichte über das Leben des Abraham auszuweiten mit dem Hinweis auf die überragende Bedeutung Abrahams als des Menschen in der Geschichte des Volkes, der das Heil an sich erfährt und für die zukünftigen Generationen und Geschlechter vermittelt"; G. S a u e r, Jesus Sirach/Ben Sira, s. 305 . 
K.P. Kowalik słusznie zauważa, że Syrach, wygłaszając pochwałę Abrahama, „podkreśla w sposób szczególny życzliwość Boga wobec wszystkich ludzi". ${ }^{117}$ Wyrazem tego jest błogosławieństwo, którego Pan będzie udzielał innym ludom za pośrednictwem - przez Izraela. W ten sposób naród wybrany staje się pośrednikiem łaskawości Najwyższego wobec całej ludzkości. ${ }^{118}$ Syr 44,21b wyraża jednocześnie wyższość Żydów oraz podkreśla ich uprzywilejowane i wyjątkowe miejsce pośród wszystkich ludów ziemi. ${ }^{119}$ Potomstwo Abrahama otrzymało niezwykle ważne zadanie wobec całej ludzkości. ${ }^{120}$ Syrach pominął jednak całkowitym milczeniem w 44,19-21 wszelkie kontakty patriarchy z obcymi ludami. ,[Syrach - przyp. autora] Koncentruje się jedynie na zachowywaniu Prawa i znaku przymierza, jakim jest obrzezanie. (...) Syrach akcentuje wierność Abrahama nie tylko po to, by zachować tożsamość własnego narodu, ale również by innych narodów nie pozbawić światła Tory". ${ }^{121}$

Szczególna rola, którą potomstwo Abrahama ma spełnić wobec innych ludów, podkreślona jest w dziele mędrca również przez fakt, że w zdecydowanej większości przypadków rzeczownik ethnos/ethnē jest użyty w kontekście, który w złym świetle stawia obce ludy - pogan. ${ }^{122}$ Jedynie w Syr 24,6 i 39,4 zostały one przedstawione w sposób pozytywny. Syr 44,21b stwierdza, że inne narody będą błogosławione, czyli będą doświadczać łaskawości i życzliwości Boga podobnie jak Izrael oraz będą otrzymywały Jego dary. Wypowiedź ta w sposób radykalny odbiega od tonu, w jakim mędrzec wypowiada się o ob-

117 K.P. K o w a 1 i k, Postać Abrahama w świetle Księgi Syracha, s. 427.

118 Zob. B.M. Z a p ff, Jesus Sirach 25 - 51, s. 323.

119 Zob. K.P. K o w a 1 i k, Postać Abrahama w świetle Księgi Syracha, s. 428; G. S a u e r, Studien zu Ben Sira, s. 97.

${ }^{120}$ „Historia Izraela otrzymała uniwersalistyczny wyraz, zachowując jednocześnie swą odrębność. Syrachowi udało się też ukazać przez pryzmat historii Abrahama i jego potomków naród wybrany jako ten, który pełni rolę pośrednika i narzędzie w ręku Boga w celu zbawienia, jakiego pragnie On udzielić człowiekowi"; K.P. K o w a 1 i k, Postać Abrahama w świetle Księgi Syracha, s. 429.

${ }^{121}$ Tamże, s. 428-429.

${ }^{122}$ Zob. Syr 4,15; 10,8.15.16; 16,6.9; 35,20; 36,1-2; 39,23; 46,6. 
cych ludach w pozostałych tekstach swej księgi. Z całą pewnością powinniśmy odczytywać Syr 44,21b w świetle Syr 44,19a („Abraham wielki ojciec mnóstwa narodów") i w relacji do tej początkowej wypowiedzi Syracha dotyczącej ojca narodu wybranego. Wydaje się, że Syr 44,21b jest logiczną konsekwencją ojcostwa patriarchy wobec wielu ludów. Również one są jego potomstwem, ale „synem pierworodnym” - „dziedzicem” jest jedynie Izrael.

\section{Liczne potomstwo, które zostanie wywyższone (44,21cd)}

Drugą obietnicą jest zapowiedź licznego potomstwa, którego liczba będzie tak wielka ,jak prochu ziemi” (zob. Syr 44,21c: plēthynai auton hōs choun tēs gēs) oraz wywyższenie go "na wzór gwiazd” (zob. Syr 44,21d: hōs astra anypsōsai to sperma autou). Zwróciliśmy już wcześniej uwagę (zob. par. 1), że tych dwóch stychów brakuje w hebrajskim oryginale Syr 44,21. Przypomnijmy, że na samym początku perykopy poświęconej pochwale Abrahama Syrach nazwał go ojcem mnóstwa narodów (zob. Syr 44,19a). ${ }^{123}$ Wypowiedź 44,21cd odnosi się zaś jedynie do potomstwa patriarchy (to sperma autou), a więc jedynie do potomków, którzy pochodzą od niego na drodze fizycznego zrodzenia dalszych pokoleń.

Pierwszy z dodanych stychów w wersji greckiej Księgi Mądrości Syracha odwołuje się do Rdz 13,16 i 28,14. ${ }^{124}$ Wyrażone w wersecie 21 b błogosławieństwo jest zrozumiałe na podstawie Rdz 28,14, choć kolejność: obietnica licznego potomstwa i błogosławieństwo mają w Syr 44,21 i Rdz 28,14 różne następstwo, o czym wspomnieliśmy już wcześniej. ${ }^{125}$

Drugi stych mówiący o potomstwie Abrahama (44,21d) jest dość specyficzny. W Starym Testamencie odniesienie liczby potomków tego patriarchy do liczby gwiazd jest dość częstym motywem

${ }^{123}$ Zob. M.C. P a $1 \mathrm{~m}$ i s a n o, Siracide, s. 418.

${ }^{124}$ Zob. B.M. Z a p ff, Jesus Sirach 25 - 51, s. 323.

${ }_{125}$ Zob. B.G. G r e g o r y, Abraham as the Jewish Ideal: Exegetical Traditions in Sirach 44:19-21, s. 80. 
(zob. Rdz 15,5; 22,17; 26,4; Wj 32,13; Pwt 1,10; 10,22; 28,62; Ne 9,23 i 1Krn 27,23). Powinniśmy zwrócić jednak uwagę, że w Syr 44,21d nie chodzi o odniesienie ilościowe, lecz jakościowe (B.M. Zapff uważa, że być może owo przejście dokonało się pod wpływem Lb 24,1726). Liczba potomków nie będzie tak wielka jak liczba gwiazd, czyli nie będą oni niedającymi się policzyć. Syr 44,21d stwierdza, że potomstwo Abrahama „będzie/zostanie wywyższone jak gwiazdy” (hōs astra anypsōsai to sperma autou). Nie chodzi więc o porównanie odnoszące się do liczby potomków patriarchy, lecz do ich wywyższenia - zajmowania ważniejszego miejsca w społeczeństwie. ${ }^{127}$ B.C. Gregory uważa, że podstawą dokonania tej zmiany jest eschatologiczna perspektywa autora tekstu greckiego Syr 44,21. ${ }^{128}$ J. Schreiner przypuszcza, że Syr 44,21cd może czynić aluzję do mądrości i bojaźni Bożej, które wywyższają tych, którzy idą za nimi w swym życiu (zob. Syr 4,11 i 40,26). ${ }^{129}$

\section{Obietnica ziemi $(44,21 e-g)$}

Ostatnia obietnica złożona Abrahamowi przez Boga, którą przywołuje Syrach w swojej pochwale tego patriarchy, odnosi się do odziedziczenia ziemi. Jego potomkowie otrzymają terytorium „od morza do morza i od rzeki aż do najdalszego krańca ziemi” (Syr 44,21fg: kataklēronomēsai autous apo thalassēs heōs thalassēs kai apo potamou heōs akrou tēs gēs). G. Pérez Rodríguez i J.G. Snaith precyzują, że Syr 44,21fg odnosi się do obszaru ograniczonego Morzem Śródziemnym, Morzem Czerwonym, na południu granicą z Egiptem, zaś na północy Eufratem. ${ }^{130}$

${ }^{126}$ Zob. B.M. Z a p ff, Jesus Sirach 25 - 51, s. 323.

127 Zob. J. S c h r e i n e r, Patriarchen im Lob der Väter (zu Sir 44), s. 439.

${ }_{128}$ Zob. B.G. G r e g o r y, Abraham as the Jewish Ideal: Exegetical Traditions in Sirach 44:19-21, s. 80 .

${ }_{129}$ Zob. J. S c h r e i n e r, Patriarchen im Lob der Väter (zu Sir 44), s. 439.

${ }_{130}$ Zob. G. Pér e z R o d rí g u e z, Eclesiástico, s. 1275; J.G. S n a i t h, Ecclesiasticus or The Wisdom of Jesus Son of Sirach, s. 219. 
Zapowiedź ta jest skutkiem poprzedniej odnoszącej się do liczby potomstwa Abrahama, skoro będzie ono tak bardzo liczne (por. Syr 44,21c), że aż niedające się policzyć, to musi ono mieszkać na wielkim obszarze ziemi, aby mogło się pomieścić. Być może Syrach nawiązał tu do sytuacji wielu spośród swych rodaków, którzy żyli poza Palestyną - w diasporze. Odwołując się do tej obietnicy złożonej ojcu ich narodu, chciał im powiedzieć, że mieszkanie pośród innych, obcych narodów nie jest żadną karą, która ich spotkała, lecz wypełnieniem zapowiedzi, którą otrzymał Abraham. ${ }^{131}$

Powinniśmy zwrócić uwagę, że w zapowiedzi dania potomstwu Abrahama ogromnego terytorium jako ich dziedzictwa Syrach nie odwołuje się do Księgi Rodzaju lecz do Ps 72,8 $8^{132}$ i tekstu hebrajskiego Za 9,10 ${ }^{133}$ (A.A. Di Lella dodaje do tych dwóch tekstów jeszcze: Wj 23,31; Pwt 11,24 i Joz 1,4134). Wyraźnie wskazują na to zbieżności literackie i treściowe. Wspólne dla tych tekstów są słowa: apo

131 „One should not rule out the possibility that the shift from a royal to nationwide, or even universal, background has something to do with the situation of the Jews in the Diaspora in Ben Sira's days. Whereas God's promises to Abraham in the Book of Genesis have a bearing only on the land of Israel, in Ben Sira's presentation the whole earth seems to be meant. Consequently the Diaspora is no longer presented as a punishment, but being the ultimate realization of God's blessing to Abraham"; P.C. B e e n t j e s, Ben Sira 44:19-23 - The Patriarchs Text, Tradition, Theology, s. 223. Por. E. J a n s e n, Das Gottesvolk und seine Geschichte. Geschichtsbild und Selbstverständnis im palästinensischen Schrifttum von Jesus Sirach bis Jehuda ha-Nasi, Neukirchener Verlag, Neukirchen 1971, s. 18; B.M. Z a p f f, Jesus Sirach $25-51$, s. 323.

${ }_{132}$ Zob. R. P e t r a g 1 i o, Il libro che contamina le mani, s. 70; T. R a s h B r ow n, Sinners, Idol-Worshippers and Fools among the Men of Hesed: Ben Sira's Pedagogy in Praise of the Fathers (Sir 44-50), s. 67; G. S a u e r, Jesus Sirach/Ben Sira, s. 305; t e n ż e, Studien zu Ben Sira, s. 98; J. S c h r e i n e r, Patriarchen im Lob der Väter (zu Sir 44), s. 439; J.G. S n a i t h, Ecclesiasticus or The Wisdom of Jesus Son of Sirach, s. 219; B.M. Z a p f f, Jesus Sirach 25 - 51, s. 323.

133 Zob. K.P. K o w a l i k, Postać Abrahama w świetle Księi Syracha, s. 430; R. P e t r a g 1 i o, Il libro che contamina le mani, s. 70-71; G. S a u e r, Jesus Sirach/ Ben Sira, s. 305; t e n ż e, Studien zu Ben Sira, s. 98.

${ }^{134}$ Zob. tamże; P.W. S ke ha n, A.A. D i L e 11 a, The Wisdom of Ben Sira, s. 505. 
thalassēs heōs thalassēs kai apo potamou heōs („od morza do morza i od rzeki aż do"). Różne zaś jest określenie granicy ziem obiecanych przez Boga potomstwu Abrahama: w Syr 44,21g mamy akrou tēs gēs („najdalszego krańca ziemi”), zaś w Ps 72,8 peratōn tēs oikoumenēs („kresów/krańców zamieszkanej ziemi/świata”). ${ }^{135}$ Mimo tego, że w ostatniej części obu obietnic zostały użyte różne słowa, to jednak ich przesłanie i treść są identyczne - tożsame. Podobne terytorium zostało wskazane także w Za 9,10 ${ }^{\mathrm{TM}}$. , ,... j jego władanie od morza do morza i od rzeki aż po kres ziemi”. W Rdz 15,18 mowa jest natomiast o terytorium znacznie mniejszym, które obejmuje „obszar od Nilu do Eufratu" (dōsō ten gēn tautèn apo tou potamou Aigyptou heōs tou potamou megalou potamou Eufratou). W Rdz 17,8 kraj dany Abrahamowi i jego potomstwu jest jeszcze mniejszy i ogranicza się „jedynie do Kanaanu" (dōsō /.../ se tèn gēn hèn paroikeis pasan tēn gēn Chanaan).

Zarówno Ps 72,8 jak i Za 9,10 są teksami mesjańskimi. Kierują więc uwagę czytelnika ku przyszłemu królestwu wyczekiwanego Mesjasza. ${ }^{136}$ Syrach, dzięki odwołaniu się do tych dwóch fragmentów, nadaje Abrahamowi, a raczej jego potomstwu, rysy mesjańskie. ${ }^{137}$ „Ogólne nawiązanie do znanych przez czytelnika proroctw nie uzupełnia ich, ani nie pogłębia. Kieruje go jedynie w stronę

135 „The one significant difference is that the domain of the king in Psalm 72 becomes the possession of Abraham's descendants in Sirach 44 (...) The emphasis ground in Psalm 72 on the subjugation of the nations (...) is absent from the account in Sirach This phenomenon may be explained in one of two way. Either the 'descendants' are all of Abraham's offspring, in which case the kingly role has been democratized, or the 'descendants' are the specific line of kings that will come forth from Abraham (Gen 17:6; 35:11). Either way, Ben Sira shifts the emphasis to the presence of Israel as a blessing for the surrounding nations"; B.G. G r e g o r y, Abraham as the Jewish Ideal: Exegetical Traditions in Sirach 44:19-21, s. 78.

136 Zob. W. P a ze r a, Pochwała ojców w księdze Jezusa Syracha, Częstochowskie Studia Teologiczne 14/1986.

137 „...chociaż Syrach jako autor pochwały wyraźnie nie podkreśla mesjańskiego znaczenia obietnicy danej Abrahamowi, mówi tylko o jego wielkości i opiece Bożej nad jego potomstwem - niemniej jednak posługuje się przy tym wzmianką z mesjańskich tradycji Izraela"; tamże, s. 291-292; por. S. P o t o c k i, 
eschatologicznych oczekiwań. Pokazując sprawiedliwego i wiernego Abrahama, jako człowieka stojącego u podstaw obietnic mesjańskich, budzi w czytelniku nadzieję, że dzięki jego osobistej wierności oraz wierności narodu wobec przymierza, jakie Bóg z nim zawarł, może on liczyć na spełnienie mesjańskich obietnic. Bóg okaże swoją sprawiedliwość i miłosierdzie, jak uczynił to w historii Abrahama, jeśli naród będzie mu wierny, podobnie jak jego ojciec Abraham". ${ }^{138}$

K.P. Kowalik dostrzega ponadto relację między Syr 44,21 i Iz 53,10-12. Opiera ją na obietnicy powszechnego panowania potomstwa Abrahama i Cierpiącego Sługi Jahwe. ${ }^{139}$ R.T. Siebeneck podkreśla, że po upadku Królestwa Południowego podczas niewoli prorocy (zob. Ez 36,24-28; Iz 54,2-3) odwoływali się do obietnicy danej Abrahamowi dotyczącej dziedziczenia Ziemi Obiecanej,

Księgi mądrościowe, w: S. Ł a c h (red.), Wstęp do Starego Testamentu, Wstęp do Pisma Świętego II; Pallottinum, Poznań-Warszawa 1973, s. 735.

${ }^{138}$ K.P. K o w a li k, Postać Abrahama w świetle Księgi Syracha, s. 430. Por. S. P o t o c k i, Mesjanizm w Księgach Mądrościowych, w: M. F i l i p i a k, S. Ł a c h (red.), Mejsasz w biblijnej historii zbawienia, Towarzystw Naukowe KUL, Lublin 1974, s. 268-270; G. S a u e r, Studien zu Ben Sira, s. 98. „Da questi dati [chodzi o Ps 72,8 i Za 9,10 - przyp. autora] emerge chiaramente come Ben Sirac lavori sull'AT. Egli legge le promesse di Dio ad Abramo $($ Gen 15,18$)$ proiettando in esse le attese del mesia, di un suo dominio universale e di un futuro sentito come tempo finale, escatologico, attese che affiorano chiaramente nel Sal 72 e in $\mathrm{Za} \mathrm{9.} \mathrm{Anche}$ in questo caso, quindi, Ben Sirac non rilegge accademicamente, a freddo, il libro della Genesi. Al contrario, lo rilegge nella prospettiva dei profeti e in un clima caratterizzato dalle nuovo speranze che animano il popolo d'Israele"; R. P e t r a g 1 i o, Il libro che contamina le mani, s. 71.

139 „...nie sposób nie zauważyć związku między obietnicami, jakie otrzymuje poddany doświadczeniu Abraham, a nagrodą spotykającą Cierpiącego Sługę z IV pieśni Izajasza (Iz 53,10-12). Nagroda licznego potomstwa i długiego życia były wprawdzie powszechnymi oczekiwaniami w Izraelu, ale warto zwrócić uwagę, że w proroctwie Izajasza dołączona jest obietnica powszechnego panowania, a właśnie taki charakter (jak wcześniej wspomnieliśmy) Syrach nadał obietnicom, jakie uzyskał Abraham"; K.P. K o w a 1 i k, Postać Abrahama w świetle Księgi Syracha, s. 431. 
ponieważ była ona niezależna od żadnych warunków i wymagań (w przeciwieństwie do przymierza na Synaju). ${ }^{140}$

Podsumowując przesłanie Syr 44,21, można stwierdzić, że Syrach, wychodząc z obietnic danych Abrahamowi, o których mówi Księga Rodzaju, o charakterze uniwersalnym (zdaniem M.C. Palmisano, punktem wyjścia refleksji mędrca jest Rdz 15,18 ${ }^{141}$ ) i odnosząc je do późniejszych zapowiedzi danych Izraelowi, łączy je z oczekiwaniami pobożnych, współczesnych mu Żydów (zob. Syr 36,11-14). W ten sposób przedstawia tego patriarchę jako podstawę oczekiwań i nadziei całego narodu, ponieważ jemu pierwszemu Bóg obiecał wielkość jego potomstwa, czyli Izraela. Zapowiedzi, które zostały złożone Abrahamowi przez Pana, są niejako fundamentem narodu wybranego. Bóg jest wierny, więc kiedyś nadejdzie wypełnienie tych zapowiedzi. Mędrzec zdaje się je umiejscawiać w czasach eschatologicznych mesjańskich. M.C. Palmisano przypuszcza, że celem powyższego przedstawienia patriarchy w greckiej wersji Pochwały Ojców mogła być próba potwierdzenia niezwykłej wspaniałości Ziemi Obiecanej. ${ }^{142}$

R. Petraglio twierdzi, że Syr 44,21 nie przedstawia potomstwa Abrahama w duchu nacjonalistycznym, lecz uniwersalistycznym. Podkreśla to, po pierwsze, błogosławieństwo, jakie będzie przekazywane przez Izraela innym narodom (w. 21b). Po wtóre, zdaniem włoskiego egzegety, rozwój liczebny i terytorialny potomstwa Abrahama nie czyni aluzji do ekspansjonizmu czy zapędów imperialistycznych, lecz kieruje myśl czytelnika ku konfederacji narodów, której przewodniczyć będzie oczekiwany Mesjasz. Tę perspektywę uniwersalistyczną otwiera i zamyka odniesienie do licznych narodów (por. Syr 44,19a i 44,21; zdaniem G. Sauera, Syrach dzięki temu

${ }^{140}$ Zob. R.T. S i e b e n e c k, May Their Bones Return to Life! - Sirarch's Praise of the Fathers, CBQ 21/1959, s. 423; por. A.A. D i L e 11 a, Ben Sira's Praise of the Ancestors of Old (Sir 44-49): The History of Israel as Parenetic Apologetics, s. 160.

141 Zob. M.C. P a $1 \mathrm{~m}$ i s a n o, Siracide, s. 418.

${ }^{142}$ „Questo soffermarsi sulle promesse divine arricchite da immaginipoetiche riguardanti la terra, è da porsi in relazione al contesto delle comunità della diaspora, agli occhi delle quali il traduttore intende forse riafferare lo splendore della terra promessa"; tamże, s. 419. 
ukazał niezwykłą wielkość Abrahama ${ }^{143}$ ). Włoski egzegeta podkreśla ponadto, że wymiar powszechny przesłania pochwały Abrahama stoi w sprzeczności z ujęciem tradycyjnym tej postaci: „Abraham, nasz ojciec". ${ }^{144}$

\section{Glówne idee teologiczne zawarte w prezentacji postaci Abrahama w Syr 44,19-21}

Mędrzec, zdaniem K.P. Kowalika, „koncentruje się jedynie na zachowaniu Prawa i znaku przymierza, jakim jest obrzezanie"'145 (B.C. Gregory potwierdza tę opinię, odwołując się do struktury koncentrycznej Syr 44,19-21, w której centrum znajduje się zawarcie przymierza i obrzezanie jako jego znak $^{146}$ ). W. Pazera twierdzi natomiast, że Syrach wychwala Abrahama przede wszystkim za jego doskonałość religijno-moralną. ${ }^{147}$ Czyni to, akcentując bardzo mocno i podkreślając wierność patriarchy. Powyższe idee mędrzec wyraził na samym początku swej pochwały Abrahama i od nich zależna jest dalsza treść perykopy poświęconej temu patriarsze, a w sposób szczególny obietnice, do których nawiązuje w 44,21. Zachowanie przymierza i Prawa oraz wierność w różnych doświadczeniach życia jest podstawą wielkości człowieka wierzącego i fundamentem jego relacji z Bogiem. ${ }^{148}$

${ }^{143}$ Zob. G. S a u e r, Studien zu Ben Sira, s. 98.

144 Zob. R. P e t r a g 1 i o, Il libro che contamina le mani, s. 71.

${ }^{145}$ K.P. K o w a l i k, Postać Abrahama w świetle Księgi Syracha, s. 428. „Wichtig für Ben Sira ist die religiöse Bezugnahme, die an dem Leben Abrahams erkannt werden kann. Diese Betonung der religiösen Haltung hat eine Tendenz hin zum kultischen Geschehen, das an Abrahams Leben nach der Sicht Ben Siras bereits abgelesen werden kann"; G. S a u e r, Jesus Sirach/Ben Sira, s. 305; por. t e n ż e, Studien zu Ben Sira, s. 100.

146 Zob. B.G. G r e g o r y, Abraham as the Jewish Ideal: Exegetical Traditions in Sirach 44:19-21, s. 77.

${ }_{147}$ Zob. W. P a z e r a, Pochwała ojców w księdze Jezusa Syracha, s. 275.

148 Zob. M.C. P a $1 \mathrm{~m}$ i s a n o, Siracide, s. 419. 
W pochwale Abrahama powinniśmy dostrzec pewien dynamizm odnoszący się do relacji z Bogiem. Wielkość człowieka opiera się na posłuszeństwie Bogu i postępowaniu kierowanym Jego nakazami. Poddanie się woli Pana jest podstawą do zawarcia przymierza przez Boga z człowiekiem, które nie stawia go na równi z Panem, lecz wymaga od niego przyjęcia konkretnej postawy - obrzezania, czyli podporządkowania się w nowy sposób Najwyższemu i przyjęcia Jego woli.

Szczególnym aspektem przedstawienia Abrahama w Syr 44,19-21 jest również uniwersalizm tej postaci i jego potomstwa. Jest on ojcem wielu narodów, a jego potomkowie będą pełnili wobec innych ludów bardzo ważną rolę pośrednika i przekaziciela łask Bożych. Mędrzec zerwał z nacjonalistycznym ekskluzywizmem i opowiedział się za uniwersalizmem, choć bardzo mocno i wyraźnie uwydatnia szczególne zadanie Izraela pośród innych narodów. ${ }^{149}$ Podkreśla to pierwszy werset pochwały Abrahama (44,19a; „ojciec mnóstwa narodów") oraz jej zakończenie (w. 21). Tworzą one ramy całej jednostki literackiej poświęconej temu patriarsze, podkreślając w ten sposób punkt wyjścia i dojścia myśli wyrażonych przez Syracha. ${ }^{150}$ Zdaniem R. Petraglio, jednym z ciekawszych tematów Syr 44,19-21 jest relacja Izraela do innych narodów. ${ }^{151}$

Szczególną uwagę powinniśmy zwrócić na mesjański charakter, jaki Syrach nadał potomstwu Abrahama. Rozpowszechni się ono nie tylko na cały świat, lecz będzie przekazicielem i pośrednikiem łaskawości i hojności Boga wobec innych narodów - stanie się ich mesjaszem. Jest to całkowicie nowy i oryginalny rys ujęcia patriarchy przez mędrca z Jerozolimy.

\footnotetext{
149 Zob. K.P. K o w a 1 i k, Postać Abrahama w świetle Księgi Syracha, s. 429.

${ }_{150}$ Zob. R. P e t r a g 1 i o, Il libro che contamina le mani, s. 71.

151 Zob. tamże, s. 72.
} 


\section{Odniesienie idei zawartych w 44,19-21 do czasów współczesnych Syrachowi}

Pochwała Abrahama nie ogranicza się jedynie do rozpamiętywania życia patriarchy, lecz jest bardzo mocnym apelem skierowanym do współczesnych autorowi Izraelitów. W Syr 44,19-21, podobnie jak w całej Pochwale Ojców, ${ }^{152}$ przede wszystkim bardzo wyraźnie dostrzegalny jest aspekt apologetyczny prezentacji ojca narodu. ${ }^{153} \mathrm{Sy}-$ rach przedstawił go jako wzór zachowywania Prawa i przymierza, zaufania Bogu, konsekwentnego wypełniania Jego nakazów oraz wierności Mu. W ten pośredni sposób zwraca się on do swoich czytelników z wezwaniem, by naśladowali te postawy i wytrwali przy $\mathrm{Bogu}^{154}$ i przeciwstawili się zagrożeniom, jakie niósł ze sobą hellenizm, który dążył do pozbawienia Żydów ich tożsamości religijno-kulturowej. Mędrzec, wygłaszając pochwałę na cześć Abrahama, apeluje do naśladowania jego postępowania, a przez to do wytrwania w wierze ojców. ${ }^{155}$ Nie możemy jednak, zwłaszcza w odniesieniu do tłumaczenia hebrajskiego oryginału na język grecki dokonanego przez wnuka mędrca, wykluczyć aspektu misyjnego, tzn. zwróce-

${ }^{152}$ Zob. A.A. D i L e 11 a, Ben Sira's Praise of the Ancestors of Old (Sir 44-49): The History of Israel as Parenetic Apologetics, s. 153-167; R.T. S i e b e n e c k, May Their Bones Return to Life! - Sirarch's Praise of the Fathers, s. 414-419.

${ }^{153}$ Zob. tami̇e, s. 423.

${ }^{154}$ „Once it is recognized that Ben Sira seeks to exhort his readers to be faithful and obedient to the covenant and that Abraham, as revealed in the Torah, exemplifies these qualities, then the emphasis on blessing becomes more understandable. The message is focused on the prosperity of the covenant community that comes from following wisdom"; B.G. Gr e g o r y, Abraham as the Jewish Ideal: Exegetical Traditions in Sirach 44:19-21, s. 79-80. Por. A.A. D i L e 11 a, Ben Sira's Praise of the Ancestors of Old (Sir 44-49): The History of Israel as Parenetic Apologetics, s. 160; G. S a u e r, Studien zu Ben Sira, s. 100-101; R.T. S i e b e n e c k, May Their Bones Return to Life! - Sirarch's Praise of the Fathers, s. 424.

155 „Il coniugare del saggio l'agire di Dio verso Abramo e quello di Abramo verso Dio avvicina anche al. Lettore di oggi lo stupore dinanzi al dono abbondante e gratuito di Dio, invitandolo alla fedeltà nella risposta"; M.C. P a $1 \mathrm{~m}$ i s a n o, Siracide, s. 419. 
nia się ku poganom w tym celu, aby przyjęli oni wiarę $\mathrm{w}$ jednego i prawdziwego Boga (prozelityzm). ${ }^{156} \mathrm{Na}$ ten cel całego dzieła zdają się wskazywać ww. 5, 13 i 34 Prologu.

Syrach, ukazując obietnice dane ojcu narodu, pragnął pobudzić współczesnych sobie do imitowania $\mathrm{w}$ ich życiu patriarchy i kroczenia jego drogami. Jeśli wytrwają $\mathrm{w}$ wierności przymierzu i Prawu, również oni otrzymają nagrodę i spełnią się także dla nich zapowiedzi dane im przez Boga, zwłaszcza te dotyczące posiadania ziemi i własnego kraju. ${ }^{157}$

Mędrzec, przypominając obietnicę licznego potomstwa oraz dania patriarsze i jego potomkom wielkiego obszaru ziemi jako dziedzictwa, wydaje się zwracać do swych rodaków żyjących w diasporze pośród obcych narodów, by tego stanu ich życia nie traktowali jako kary, lecz jako spełnianie się zapowiedzi danej ich ojcu - Abrahamowi. Mówiąc natomiast o pośrednictwie Izraela w udzielaniu przez Boga błogosławieństwa innym ludom, z jednej strony ukazuje wyjątkową rolę i niezwykłe zadania, jakie ma do spełnienia naród wybrany wobec pogan, z drugiej zaś wywyższa go ponad nich, stawiając w uprzywilejowanej pozycji. W ten sposób zrywa z nacjonalizmem i ekskluzywizmem, opowiadając się za uniwersalistyczną wizją świata i ludzi, a zarazem uznaje wyjątkową rolę Izraela, podkreślając jego wielkość i niezwykłość. Żydzi nie powinni czuć się gorsi od ludów zhellenizowanych, wręcz przeciwnie, winni być dumni z tego, że są potomstwem Abrahama. Podstawę do tej świadomości i takiej wizji świata oraz ich roli wobec innych daje im pochwała ich ojca zawarta w Syr 44,19-21.

${ }^{156}$ Był to m. in. jeden z celów, który przyświecał powstaniu Septuaginty; zob. M.K.H. P e t e r s, Septuagint, w: D.N. F r e e d m a n (red.), The Anchor Bible Dictionary, t. V, s. 1097.

157 „When Sirach wrote, the Jews found themselves dispossessed of the land which was theirs by promise. In recalling the promise Sirach insists that the son of promise had nothing to fear from Hellenism because the divine origin of the promise assured its realization"; R.T. S i e b e n e c k, May Their Bones Return to Life! - Sirarch's Praise of the Fathers, s. 423. 
Syrach, przypominając przymierze, które Bóg zawarł z Abrahamem, pragnie ożywić nadzieję swych rodaków, że obietnice związane z nim są nadal aktualne, nie zostały wycofane i nie uległy przedawnieniu, ponieważ przymierze to było bezwarunkowe, nieodwołalne i nieodwracalne. Trwa więc i nadal obowiązuje, dlatego też należy oczekiwać wypełnienia wszystkich zapowiedzi z nim związanych (liczne potomstwo i odziedziczenie ziemi). ${ }^{158}$

Syrach jest pierwszym spośród mędrców Izraela, który połączył tradycje mądrościowe $\mathrm{z}$ historią swego narodu. ${ }^{159}$ Dokonał tego, ukazując, jak mądrość działała i jak była realizowana w życiu wybitnych postaci z przeszłości. Wśród nich nie mogło zabraknąć Abrahama. Syr 44,19-21 jest pierwszym tekstem w Biblii, w którym autor dokonał reinterpretacji postaci tego patriarchy. ${ }^{160}$ Mimo tego, że jest ona dość krótka, to jednak bardzo bogata z punktu widzenia teologicznego. ${ }^{161}$ W swoim przedstawieniu postaci ojca narodu żydowskiego mędrzec z Jerozolimy oparł się przede wszystkim na tekstach z Księgi Rodzaju, które przedstawiają życie i działalność Abrahama, ale wykorzystał także poglądy pozabiblijnych tradycji judaistycznych dotyczące tej postaci, czemu dał również wyraz w Syr 44,19-21. Należy jednak

158 „This is a covenant of divine commitment that is unconditional, irrevocable, and irreversible. Ben Sira reminds his fellow Jews that this covenant, which made Israel God's Chosen People, is still in effect; and accordingly, they have every reason to believe that the Lord is with them now even though they no longer were in control of the land that the Lord had promised to give to Abraham and to his descendants"; A.A. D i L e 11 a, Ben Sira's Praise of the Ancestors of Old (Sir 44-49): The History of Israel as Parenetic Apologetics, s. 160.

159 Zob. R.T. S i e b e n e c k, May Their Bones Return to Life! - Sirarch's Praise of the Fathers, s. 411.

160 ,...teksty te [księgi deuterokanoniczne ST - przyp. autora] - mimo odniesienia do postaci Abrahama - nie podejmują reinterpretacji jego dziejów. Podobny charakter mają teksty apokryfów Biblii Greckiej nawiązujące do postaci Abrahama"; K.P. K o w a li k, Postać Abrahama w świetle Księi Syracha, s. 422.

161 Zob. M.C. P a $1 \mathrm{~m}$ i s a n o, Siracide, s. 419. 
podkreślić, że głównym, podstawowym, źródłem dla Syracha był tekst biblijny. Mędrzec dokonał bardzo precyzyjnego wyboru wydarzeń z życia Abrahama ${ }^{162}$ i związanych z nimi idei teologicznych, ${ }^{163}$ tak aby ukazać go jako wzór dla sobie współczesnych - ideał i model do naśladowania w zachowywaniu przymierza z Bogiem. ${ }^{164}$ Syrach,

162 Spośród ważnych wydarzeń z życia Abrahama Syrach pominął całkowitym milczeniem najważniejsze z nich, które było zarazem fundamentalne dla życia patriarchy, a mianowicie jego powołanie (zob. Rdz 12,1-3). Nie czyni do niego żadnego odniesienia explicite, możemy jedynie dostrzec aluzje nie wprost i dość niejasne, które bazują jedynie na domysłach i przypuszczeniach (zob. Syr 44,20a i 22a-b). Ponadto mędrzec nie wspomina nic o trudnych relacjach Abrahama z innymi narodami. Pominął też całkowitym milczeniem wszystkie wydarzenia, które ukazałyby stosunki międzyosobowe w rodzinie patriarchy i wynikające z nich trudności (Sara, Hagar, Lot). Syr 44,19-21 nie wspomina również o wędrówkach Abrahama (por. Rdz 12-13; 20), wojnie z królami mezopotamskimi i spotkaniu z Melchizedekiem (por. Rdz 14), o podjęciu przez niego Boga i zniszczeniu Sodomy i Gomory (por. Rdz 18-19) oraz nabyciu grobu w Makpela (por. Rdz 23). „L'immagine di Abramo che ne risulta è un'immagine per un verso semplificata (passano infatti sotto silenzio alcuni momenti meno brillanti della sua vita, come il suo tacere la vera identità di Sara, cfr. Gen 12,10-20)”; tamże, s. 419. „Es fält auf, dass Ben Sira nicht bei der «Berufung»= «Erwählung», etwa nach Gen 12 oder 15 beginnt, sondern gleichsam von hinten her, vom Erfolg des bereits erlebten Lebens Abrahams rückwärts schließt"; G. S a u e r, Studien zu Ben Sira, s. 931; por. t e n ż e, Studien zu Ben Sira, s. 99. Por. K.P. K o w a 1 i k, Postać Abrahama w świetle Księgi Syracha, s. 428; Maertens, L'Éloge des Pères, s. 37; G. S a u e r, Jesus Sirach/Ben Sira, s. 305; t e n ż e, Studien zu Ben Sira, s. 99.

163 „As someone who participates in the rich wisdom tradition of ancient Israel, Ben Sira shows himself to be deeply immersed in the theology, concepts, and Scriptures of his community. His dependence on these traditions is evident both in his broad hermeneutical perspective and in his recounting of Israel's history. Yet Ben Sira does not simply repeat the past but expands on it, drawing on the texts and interpretive traditions in a way that was unique among wisdom literature"; B.G. Gre g or y, Abraham as the Jewish Ideal: Exegetical Traditions in Sirach 44:19-21, s. 81.

${ }^{164}$ „W jego [Abrahama - przyp. autora] charakterystyce (44,19-21) Syrach dokonał najpierw idealizacji, podkreślając jego niezwykłą wierność Prawu, nieskazitelność życia, wytrwałość w doświadczeniu. Postać Abrahama staje się jednostką nie mającą odpowiednika w historii narodu. Nikt nie był w stanie go prześcignąć, a nawet mu dorównać”; K.P. K o w a 1 i k, Postać Abrahama w świetle Księgi Syracha, s. 430. 
prezentując patriarchę, przekazał również bardzo ważną ideę, która koncentruje się na przyszłej wielkości Izraela i szczególnej roli, jaką ma on odegrać wobec innych narodów.

Główny cel reinterpretacji Abrahama w Syr 44,19-21 możemy określić jako polemiczno-apologetyczny. Mędrzec nie tylko chciał bronić tożsamości religijno-kulturowej swego narodu przez wezwanie do wierności przymierzu i zachowywania Prawa, ale pragnął także wlać we współczesnym sobie ludziom nadzieję wobec zagrożenia ze strony hellenizmu oraz wzniecić w nich dumę z przynależności do Izraela. K.P. Kowalik uważa, że Syrach tak przedstawił postać Abrahama, że stała się ona paradygmatem dla prezentacji innych osób w całej Pochwale Ojców, którym jest zmaganie o wierność Bogu w różnych doświadczeniach życiowych. ${ }^{165}$

ks. Andrzej PIWOWAR

Słowa kluczowe: Abraham, Pochwała Ojców, Księga Syracha, Syr 44,19-21

Keywords: Abraham, Praise of the Fathers, The Book of Sirach, Sir 44:19-21

Abraham in Sirach's Praise of the Fathers (Sir 44:19-21)

\section{Summary}

The article is devoted to the presentation of Abraham in the Greek text of the Praise of the Fathers (Sir 44:19-21). Only 13 verses are devoted to the patriarch, but his description carries a wealth of theological meaning. Sirach presents Moses as an ideal and a model to follow for himself, his contemporaries and all believers (cf. Sir 44:19b). First of all, he emphasizes Abraham's moral and religious perfection (cf. Sir 44:20), which manifested itself in his abiding by the Law (cf. Sir 44:20a) and respecting the covenant with God, reflected primarily through the sign of circumcision (cf. Sir 44:20bc). Abraham was completely loyal to God and proved his loyalty during a trial (cf. Sir 44:20d). Sirach stresses especially one's attitude to the covenant with God as the most important aspect of a believer's life; in this respect Abraham should be a model to emulate. In the final part of the

${ }^{165}$ Zob. tamże, s. 425. 
fragment the sage focuses on the result of Abraham's faithfulness to God. The Lord promised him numerous offspring (cf. Sir 44:21cd) and an inheritance encompassing the whole Earth (cf. Sir 44:21e-g). Sirach emphasizes the special position of Abraham's offspring among the nations (the latter will receive blessings through the former; cf. Sir 44:21b). What is more, Abraham's offspring will be elevated over other nations (cf. Sir 44:21d). What is particularly noteworthy in Sirach's reinterpretation of Abraham is that the patriarch respected the Law and that the sage attributed Messianic features to him. 